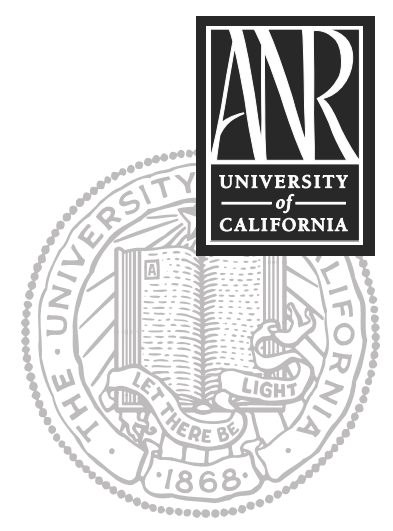

UNIVERSITY OF CALIFORNIA

Division of Agriculture and Natural Resources http://anrcatalog.ucdavis.edu

\title{
Raising Game Birds
}

RALPH A. ERNST, UC Cooperative Extension Poultry Specialist Emeritus, UC Davis; ALLEN E. WOODARD, Specialist (retired), UC Davis; PRAN VOHRA, Professor of Avian Sciences (retired), UC Davis; and Carol Cardona, Extension Veterinarian, UC Davis.

\section{CONTENTS}

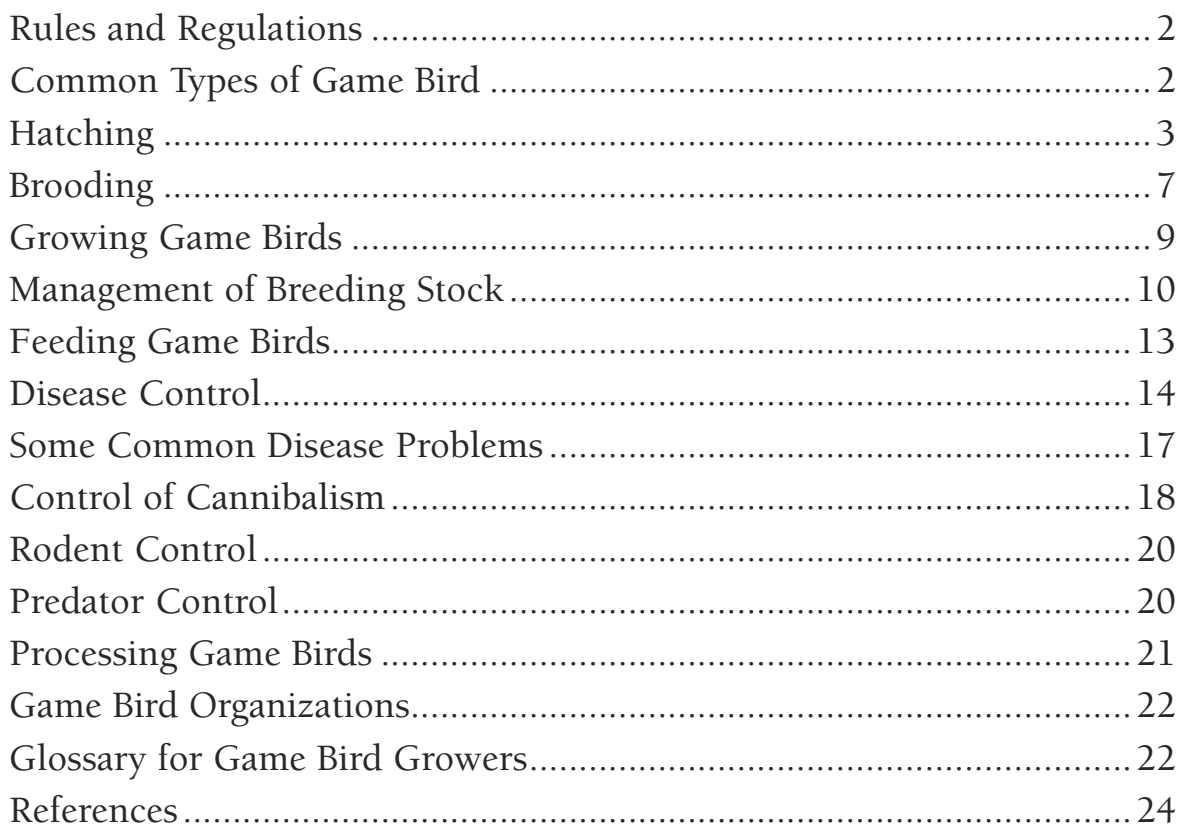

There are many reasons to participate in game bird farming. It can be an enjoyable hobby, a rewarding 4-H project, a means of establishing or increasing local game bird populations, or a business venture.

The stocking of game birds to establish or increase a resident population for hunting is a long-established practice among professional wildlife managers, landowners, and sportsmen. This type of program can only succeed if the stocked birds are placed in a suitable habitat to ensure their survival and future breeding.

Since public lands available for hunting upland game birds have diminished considerably, many sportsmen are turning to licensed shooting clubs for hunting. Most clubs operate on a put-and-take basis and attempt to harvest a high percentage of stocked game birds. Some people earn all or part of their income raising game birds. Whatever your reasons for considering a game bird farming enterprise, consider these three important factors:

Game birds must be regarded as a wildlife crop. There are successful, proven methods that will help you raise and harvest a good crop. Game birds are not an incidental crop that will produce well without much attention. You will need to devote a substantial amount of time to provide the intensive care they require.

If your motive is to establish or increase local game bird populations, your efforts will be fruitless unless the habitat you are stocking is suitable for those game bird species. No animal can survive for long in an unfavorable habitat. You need to recognize that conditions vary at different locations and that game bird species vary in their habitat requirements. Contact your state Department of Fish and Game for relevant local regulations and habitat information.

Every business operates on the principle of supply and demand. If you are considering game bird farming as a business venture, do so only after you determine 
- current and potential markets and demand

- total projected costs, including initial investment, labor, transportation, and taxes

- competition for the markets you are entering

- local zoning regulations or requirements that relate to confined animal production

- design requirements for bird housing, pens, and facilities

- the availability of feed, equipment, supplies, and veterinary care in the area

- sources for game bird stock

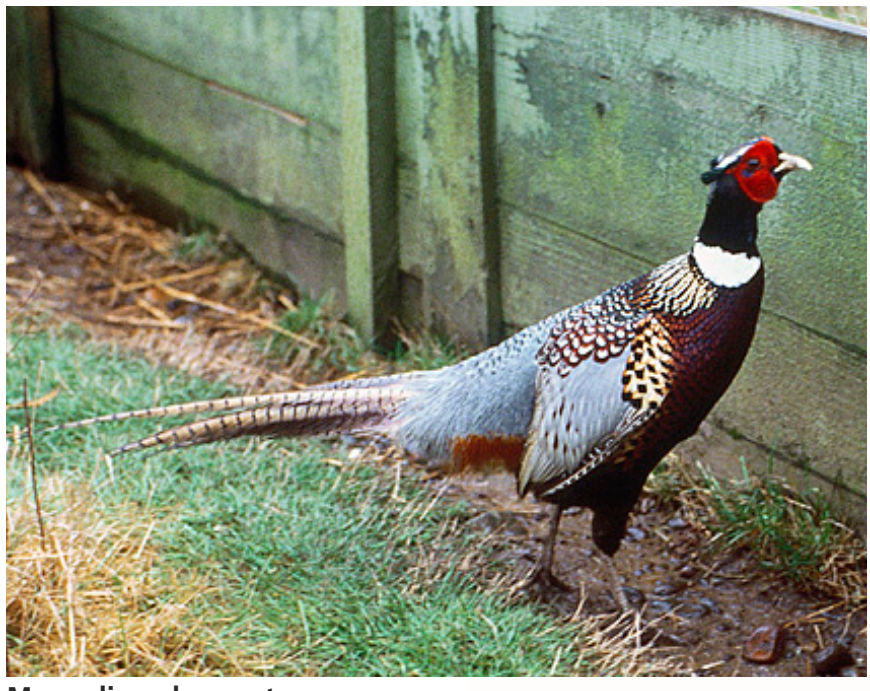

Mongolian pheasant

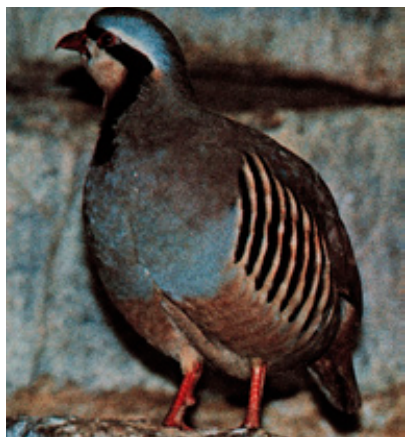

chukar partridge

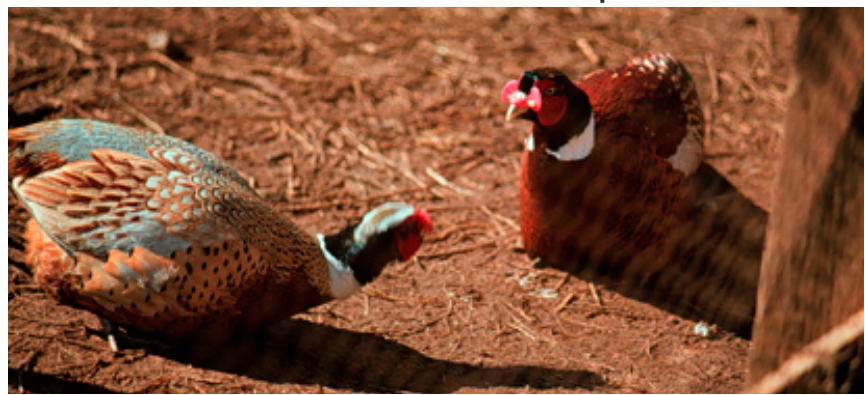

Mongolian pheasant

Figure 1. Some of the common types of game bird grown for hunting or slaughter.
Good management practices will take most of the guesswork out of a bird farming operation, whatever its size or purpose. This publication describes proven methods of game bird husbandry.

\section{RULES AND REGULATIONS}

In most states, a Department of Fish and Game establishes and enforces rules and regulations for the management of wildlife. Because of the agencies' interest in hunting and fishing, the rules and regulations tend to be designed to encourage the presence of native and certain exotic species while discouraging the presence of others. Most states require that an individual acquire a game breeder's license before he or she can obtain and keep game birds. In California, you can direct any questions about the legal requirements for game bird raising and release to the California Department of Fish and Game, http://www.dfg.ca.gov.

\section{COMMON TYPES OF GAME BIRD}

Just five species account for most of the game birds raised in California (fig. 1). The Chinese pheasant was imported into the United States as a game bird and has been established in many parts of North America. It is a small pheasant that flies well and is a popular bird for release by many hunting clubs.

The Mongolian pheasant is larger and heavier than the Chinese pheasant. Its plumage features an incomplete neck ring (in contrast to the Chinese pheasant's complete neck ring). It is often raised in captivity as a table bird and is preferred by some hunters because it is a slower flyer and it has more meat when processed.

The chukar partridge is a beautiful game bird. Its native range runs from Greece to India. It is widely raised in North America for hunting and as a meat bird. It has been successfully established as a wild game bird in several parts of the western United States.

The bobwhite quail is native to eastern North America. It has been raised in captivity for many years and propagators have developed strains of the bird with different body size and flight characteristics.

Japanese quail were domesticated in Japan and have been raised in captivity for thousands of years. Some histo-
Japanese quail (coturnix, pharaoh quail) 
rians believe that these quail may have been in confinement longer than the domestic chicken. A Japanese quail reaches sexual maturity at about 6 weeks of age. Body weights range from roughly 100 to 150 grams for the quail stock that was originally imported from Japan. Selective breeding for meat type has resulted in birds with a body weight that can be three times this.

Japanese quail are prolific layers. The average egg weight is about 10 percent of the hen's body weight (more than twice the egg weight ratio that is typical for most birds). Because of these characteristics, Japanese quail are raised extensively for egg and meat production. They are not good fliers when raised in close confinement, and therefore are not commonly used for hunting.

\section{HATCHING}

We strongly recommend that beginners start with day-old chicks or with eggs purchased from a reputable game bird breeder who can supply a product that is reasonably free of disease. In California, a list of game bird breeders with stock for sale is available online from the state Department of Fish and Game at this URL: http://www.dfg.ca.gov/licensing/pdffiles/licensedgamebreeders.pdf.

\section{Hatchery and Equipment}

Your needs for a hatchery will depend on the size of your operation (fig. 2). A commercial hatchery should have concrete floors sloped to a large drain in every room to facilitate cleaning. The walls and ceiling should be constructed of water-impervious materials.

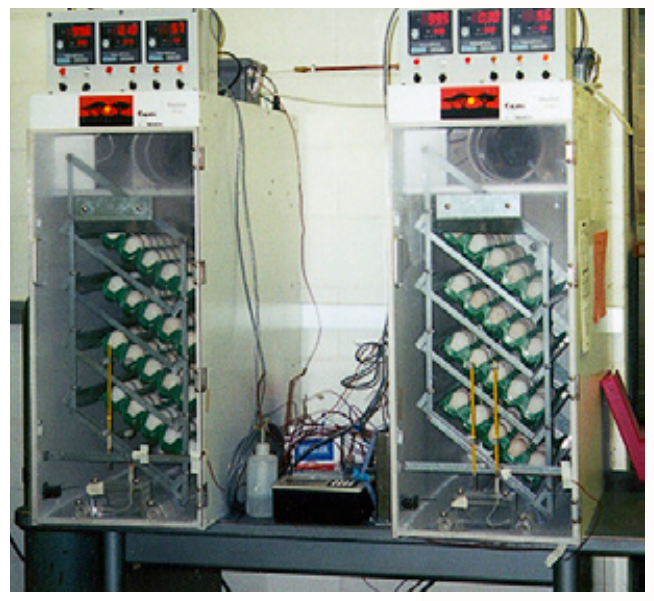

Figure 2. Small incubators appropriate for hatching game bird eggs.

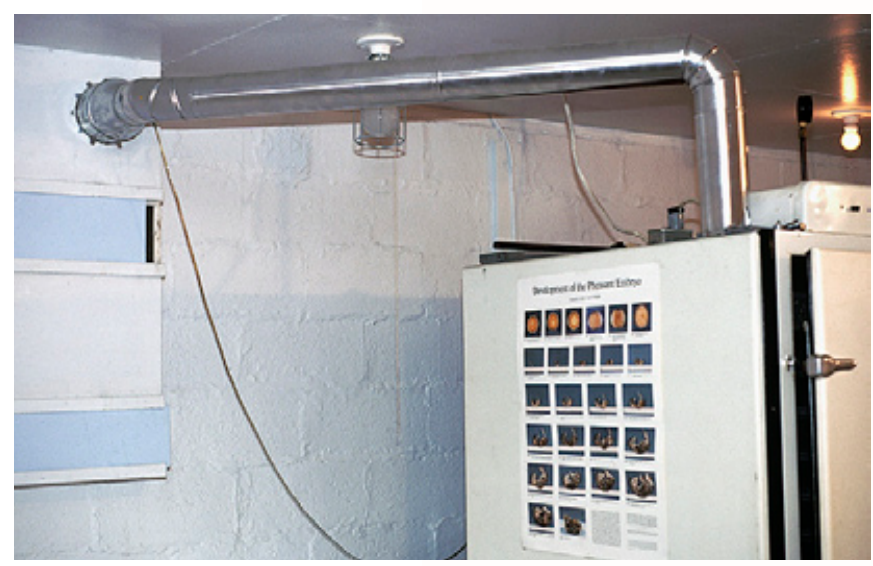

Figure 3. Game bird incubator with an exhaust duct to the exterior of the hatchery.
A hatchery should be well ventilated with a system designed to provide a uniform supply of clean air. Maintain the setting and hatching room temperature between $65^{\circ}$ and $80^{\circ} \mathrm{F}\left(18.3^{\circ}\right.$ and $\left.26.7^{\circ} \mathrm{C}\right)$. In the summer, especially in dry areas, evaporative cooling of the incoming air is preferable to mechanical refrigeration because it increases the humidity. You will have to provide some heat in most locations during the colder months. It is better to vent the exhaust air outside the hatchery rather than to recycle the contaminated air into the machines (fig. 3).

Adequate oxygen levels and carbon dioxide removal are necessary for embryo development, but the main functions of ventilation are to control the temperature and to dilute the concentration of airborne microorganisms during the hatch. In a commercial game bird hatchery, the hatcher and equipment-cleaning area should be housed in a separate room with its own ventilation system to keep the fluff and dust from the hatch away from the incubators, clean eggs, and clean equipment. With a smaller operation, this degree of separation may not be feasible.

Some incubators have a hatcher attached. In this case, you will want to ventilate the room to keep the dirty air away from the incubator as much as possible.

It is possible to both set and hatch game bird eggs in a single machine, but this is only practical if you have a very small group of eggs. If you are planning to incubate 100 or more eggs weekly, you will want to purchase one or more machines for setting and another for hatching. Eggs should be transferred from setting trays 
to hatching baskets 3 days before the projected hatch date. At that time, changes are also made in temperature and humidity (see table 2 ).

When you purchase an incubator or hatcher, select one that is well constructed. The machine should have automatic temperature control that maintains the temperature within a narrow range (within $\pm 1 / 4^{\circ} \mathrm{F}\left[ \pm 0.15^{\circ} \mathrm{C}\right]$ is best). Other essential features for a commercial operation are automatic turning of the eggs, humidity control, and forced air movement.

Another important consideration is how easy it is to wash and sanitize the cabinet. Interior machine surfaces should be impervious to water, cleaning compounds, and disinfectants. Wood is durable and a good insulator, but it is difficult to clean and nearly impossible to sterilize. Many wooden machines can be improved if you coat the interior surfaces with epoxy resin. Do not use lead-based paints: lead is toxic to chicks. Other important considerations are the reliability of the mechanical systems, the ease of repair, and the availability of service and spare parts.

Some machines are designed to operate better with two or three ages of eggs in one incubator. This makes cleaning more difficult, but you can still clean the interior surfaces of the machine as you add new eggs or by removing a few trays at a time for cleaning.

\section{Care of Eggs}

Always wash your hands thoroughly with a disinfectant soap before handling eggs. If the eggs sweat when you remove them from the holding room, reduce either the humidity or the temperature of the room where eggs are placed in trays. You may also

Table 1. Recommended egg holding-room temperature for various storage times*

\begin{tabular}{|l|c|c|}
\hline & \multicolumn{2}{|c|}{ Maximum storage temperature } \\
\hline Duration of storage & ${ }^{\circ} \mathrm{F}$ & ${ }^{\circ} \mathrm{C}$ \\
\hline 1 days & 70 & 21.1 \\
\hline $2-4$ days & 65 & 8.3 \\
\hline $5-10$ days & 60 & 15.6 \\
\hline over 10 days & 55 & 12.8 \\
\hline
\end{tabular}

* Lowest recommended storage temperature is $50^{\circ} \mathrm{F}$. be able to increase the temperature in the egg holding room to the levels shown in table 1, depending on the length of egg storage.

Set only nest-clean eggs. Cracked, thin-shelled, misshapen, or abnormal-sized eggs should not be set as they tend to hatch very poorly and are likely to contaminate other eggs or chicks. Eggs that have been stored require a longer incubation period than fresh eggs, so you should make sure to pre-set them or allow them more time to hatch. Eggs that have been stored for 2 weeks should be pre-set for 10 hours; those stored for 3 weeks, for 18 hours.

\section{Hatchery and Hatching Egg Disinfection}

Hatchery operators have long used formaldehyde gas fumigation to reduce contamination on eggs, incubators, and hatchers. Label registration for this use was withdrawn for a time due to its potential for human toxicity, but the U.S. Environmental Protection Agency (EPA) has again registered several formaldehyde products for incubator and hatching egg fumigation. At the time of this writing, no formaldehyde product is registered in California for this use. Even where it is legally allowed, some producers prefer not to use formaldehyde in hatcheries due to its human toxicity, but several alternative disinfectants are available for sanitation of eggs and equipment (see UC ANR Publication 8120, Hatching Egg Sanitation: The Key Step in Successful Storage and Production).

\section{Incubation}

Proper incubation is not difficult, but certain procedures should be followed to ensure success. First, clean the equipment. Wash incubators and hatchers with a detergent solution and then rinse and sanitize them. Soak egg trays in a detergent solution and then scrub, rinse, and sanitize them. 
Table 2. Recommended conditions for incubation of pheasant, partridge, and quail eggs

\begin{tabular}{|l|c|c|c|c|} 
& \multicolumn{2}{|c|}{ Incubation temperature } & \multicolumn{2}{c|}{ Hatching temperature } \\
\hline Machine type & Dry bulb & Wet bulb & Dry bulb & Wet bulb \\
\hline Fan-ventilated & $99.5^{\circ}-100^{\circ} \mathrm{F}$ & $82^{\circ}-86^{\circ} \mathrm{F}$ & $98.5^{\circ} \mathrm{F}$ & $90^{\circ}-92^{\circ} \mathrm{F}$ \\
& $\left(37.5^{\circ}-37.8^{\circ} \mathrm{C}\right)$ & $\left(27.8^{\circ}-28.3^{\circ} \mathrm{C}\right)$ & $\left(37^{\circ} \mathrm{C}\right)$ & $\left(32.2^{\circ}-33.4^{\circ} \mathrm{C}\right)$ \\
\hline Still-air & $102^{\circ}-103^{\circ} \mathrm{F}$ & $88^{\circ}-90^{\circ} \mathrm{F}^{*}$ & $100^{\circ}-101^{\circ} \mathrm{F}$ & $88^{\circ}-92^{\circ} \mathrm{F}^{*}$ \\
& $\left(38.9^{\circ}-39.4^{\circ} \mathrm{C}\right)$ & $\left(31.1^{\circ}-33.3^{\circ} \mathrm{C}\right)$ & $\left(37.8^{\circ}-38.3^{\circ} \mathrm{C}\right)$ & $\left(31.1^{\circ}-33.3^{\circ} \mathrm{C}\right)$ \\
\hline
\end{tabular}

*Wet bulb temperature is not an accurate measure of relative humidity in still-air incubators.
After the incubator is clean, make sure to start, test, and adjust it. Operate the machine for at least 24 hours before you use it to set eggs. Put a record sheet on each machine and record their wet and dry bulb temperatures at least twice a day. The information in table 2 specifies the required incubation conditions for pheasant, partridge, and quail eggs.

Follow the instructions provided with your incubator to adjust the air vents, but remember that some ventilation is necessary at all times to maintain proper levels of oxygen and carbon dioxide. Ventilation requirements increase as the embryos grow.

Eggs can be set either with the large (blunt) end up or horizontally, but never with the small (pointed) end up. They should be turned every 2 to 4 hours during the first two-thirds of the incubation period or until you transfer them to the hatcher, but they should never be turned during the hatching period. If no mechanical turning apparatus is available, turn the eggs by hand three or more times per day (starting as early and finishing as late in the day as possible).

When you set the eggs, record the setting date, egg source, number of eggs set, and expected transfer and hatch dates. Attach a card with this information to the setting trays so that each set will always be easy to identify.

\section{Hatchery Records}

Keep a record of the results of each hatch, including information from candling and egg examination as well as the number of chicks obtained. These records are useful in pinpointing problems when the hatch rate is poor. Reasonable goals for most game bird eggs are 96 percent true fertility, 93 percent candled fertility, 87 percent hatch of eggs set, and less than 3 percent cracked and unsettable eggs.

\section{Examination of Eggs}

Game bird eggs should be candled after 7 to 10 days of incubation and again at transfer to the hatcher ( 3 to 4 days before hatch). You will want to use a strong candling light since most game bird species have pigmented eggshells that obstruct light transmission. Remove and count all eggs that are clear or contain blood rings. All of the eggs that are candled out (or a representative sample of at least 50) should be opened, examined, and classified before you discard them.

Egg examination is most conveniently performed in a well-lighted area equipped with a sink and a garbage disposal. Open each egg by breaking the large end and removing the shell and shell membranes on this end with the thumb and forefinger. Carefully open any egg that has a blood ring to avoid loss of any embryo that might be present near the air cell. Record the type of failure for each egg as it is identified. Types are listed below.

Early candling will allow you to separate and remove clears and dead embryos. When you examine the clears by breaking them open, you will find some or all of the following types:

- true infertile egg

- fertile no development (fertile egg that failed to develop)

- positive development (showing cellular development but not blood)

The eggs that show some development (blood rings) but an abnormal appearance will reveal the following types on breakout: 
- blastoderm without embryo (BWE) (a blood ring appears, but no embryo)

- early dead embryo

For assistance in identifying these types see UC ANR Publication 8134, Egg Candling and Breakout Analysis.

You also need to examine the eggs removed after the second candling. Most of these will be dead embryos, but an occasional candling error may lead you to open an egg that contains a live embryo and should therefore be dropped from the sample count. You may also come across one of the previously described types that was missed on the first candling. Go back and record that on the record from the earlier candling and examination.

Table 3. Incubation periods for several popular game birds

\begin{tabular}{|l|c|}
\hline Game bird & Days of incubation \\
\hline $\begin{array}{l}\text { Chinese ring-necked } \\
\text { pheasant }\end{array}$ & $23-24$ \\
\hline $\begin{array}{l}\text { Mongolian ring-necked } \\
\text { pheasant }\end{array}$ & $24-25$ \\
\hline Red-legged partridge & $23-24$ \\
\hline Hungarian partridge & $24-25$ \\
\hline Bobwhite quail & $23-24$ \\
\hline California quail & $23-24$ \\
\hline Japanese quail & $17-18$ \\
\hline Wild turkey & 28 \\
\hline
\end{tabular}

\section{Transfer to Hatcher}

The data in table 3 give the incubation time requirements for several types of game birds. Transfer your eggs to the hatcher 3 or 4 days before the projected hatch date. Adjust the dry bulb temperature down $1 / 2^{\circ}$ to $1^{\circ} \mathrm{F}\left(0.3^{\circ}\right.$ to $\left.0.5^{\circ} \mathrm{C}\right)$ and increase the wet bulb temperature to $88^{\circ}$ to $92^{\circ} \mathrm{F}\left(31.1^{\circ}\right.$ to $\left.33.3^{\circ} \mathrm{C}\right)$; this will provide optimum hatching conditions. You may need to vary these wet bulb settings in order to get the correct moisture loss from eggs under your specific conditions. You can estimate the correct amount of dry down either during candling, by examining the eggs that fail to hatch, or by weighing a sample of eggs before and after incubation. The total moisture loss should be about 15 percent at hatching time.

When the hatch is completed, sort, count, and place the chicks into new chick boxes or plastic boxes that have been cleaned, sanitized, and equipped with new pads. Make sure that you have allowed enough time for the hatch to be completed and for the chicks to dry, but do not keep the chicks in the hatcher longer than necessary or they will become dehydrated. When the hatch nears completion and 1 to 5 percent of the chicks are still wet, it is time to remove the hatch.

Record and break out all unhatched eggs or a sample of 50 as previously described. Give particular attention to the moisture (dry-down) condition and the embryo position (in normal position, the head is under the right wing). There usually are some abnormal embryos with missing or duplicate parts or abnormal parts in this group. If you find significant numbers with the same abnormality, be sure to note this as it would suggest that your breeding stock carries a lethal or sublethal gene.

\section{Sanitation}

After you remove the chicks, thoroughly clean the hatcher and trays. After cleaning, fumigate or apply a good sanitizer to the machine, taking care to protect any electrical parts.

Sanitation is always 90 percent cleaning. Disinfectants are valuable in maintaining a sanitary hatchery, but they will not compensate for a poor cleaning job. The following is a good washing procedure:

1. Empty refuse.

2. Soak in a detergent solution, if necessary, to loosen dirt.

3. Wash with hot water and detergent.

4. Rinse.

5. Disinfect (steps 4 and 5 may be combined if the disinfectant is nontoxic). 


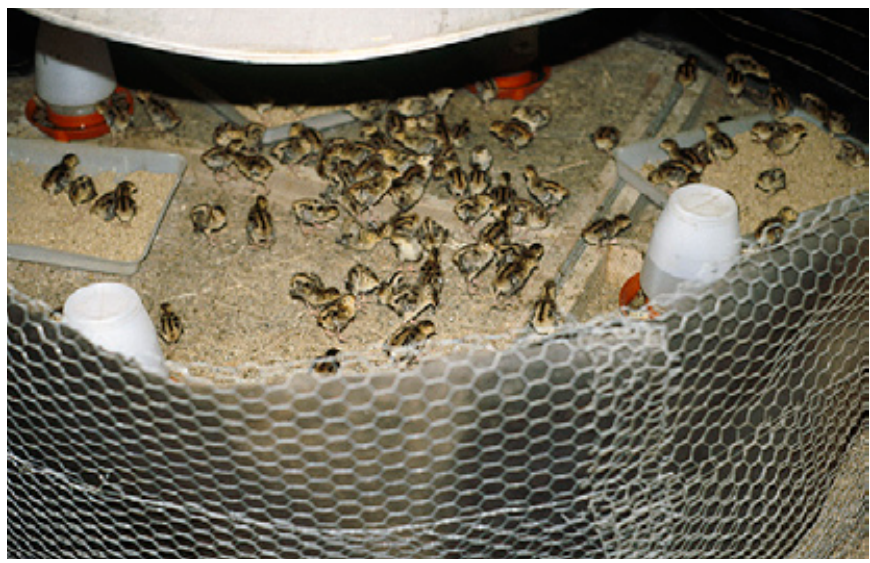

Figure 4. Cool-room, floor brooding with a radiant propane brooder.

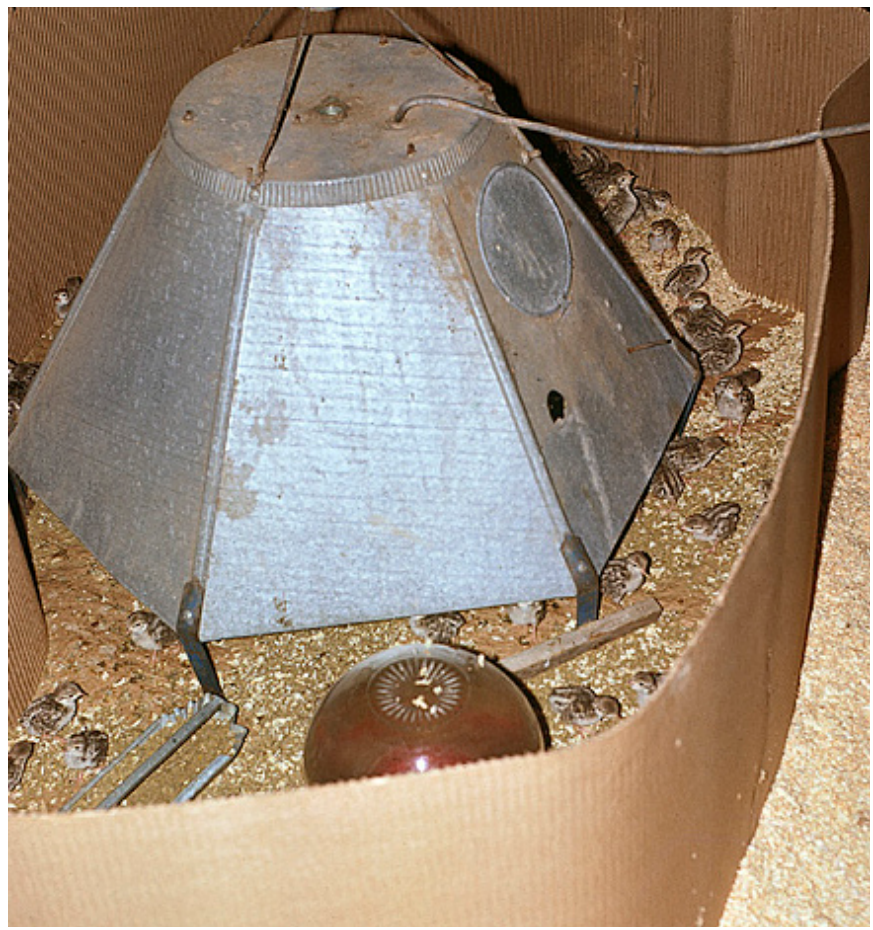

Figure 5. Electric hover brooder showing brooder ring, brooder guard, and equipment.
An equipment washing area should be provided near the hatcher(s). A reasonable arrangement for a small hatchery would be as follows:

Room A: egg processing and traying area, egg holding room, incubators, storage room for clean equipment.

Room B: hatcher(s), chick holding area, equipment washing area, outside door to refuse collection area.

\section{BROODING}

Artificial brooding of domestic poultry and game birds has been so successful that natural brooding has become obsolete. There are two basic types of brooding in common use: cool-room brooding (figs. 4 and 5) and warm-room brooding. In the former, birds are provided a heat source with an adjacent area held at a lower temperature. This system has several advantages including faster feathering in the chicks and easier temperature regulation. With warm-room brooding, a heating system maintains the entire house or room at the desired temperature.

\section{Heat Sources}

Many types of heat sources can be used successfully for brooding. These include heat lamps, hot water pipes, or stoves that use natural gas, liquid petroleum (LP or propane) gas, fuel oil, coal, wood, or electricity. Stoves using LP gas or natural gas are the most popular because of their economy and convenience. Either radiant (fig. 4) or hover-type (fig. 5) brooder stoves can be used. With a radiant brooder, you have the advantage that the chicks are easier to observe.

With cool-room brooding, the temperature of the hover area at chick height is usually adjusted to $95^{\circ} \mathrm{F}\left(35^{\circ} \mathrm{C}\right)$ during the first week and then decreased approximately $5^{\circ} \mathrm{F}\left(2.8^{\circ} \mathrm{C}\right)$ per week until it reaches room temperature. Measure these temperatures at bird height near the edge of the brooding stove. Quail, partridge, and wild turkeys seem to require slightly higher brooding temperatures than pheasants. The best guide to temperature adjustment is to watch the chicks' behavior. If the temperature is too low, they will huddle under the stove. If they avoid the heated area completely, the temperature is too high. With warm-room brooding, you can start chicks at a room temperature of approximately $90^{\circ} \mathrm{F}\left(32.2^{\circ} \mathrm{C}\right)$. As with cold-room brooding, this temperature should decrease as they get older.

\section{Light and Ventilation}

It is important that brooding pens be properly lighted during the first week so that young chicks will learn to eat and drink. Use a 16-hour day-length with an intensity of 2 or more foot-candles (20 lux) during the first week; after that, you can reduce the light to 12 hours per day or switch to natural daylight if desired.

A brooder house or room that houses starting batteries needs to be well ventilated to keep moisture and ammonia from building up. If you smell ammonia or observe 


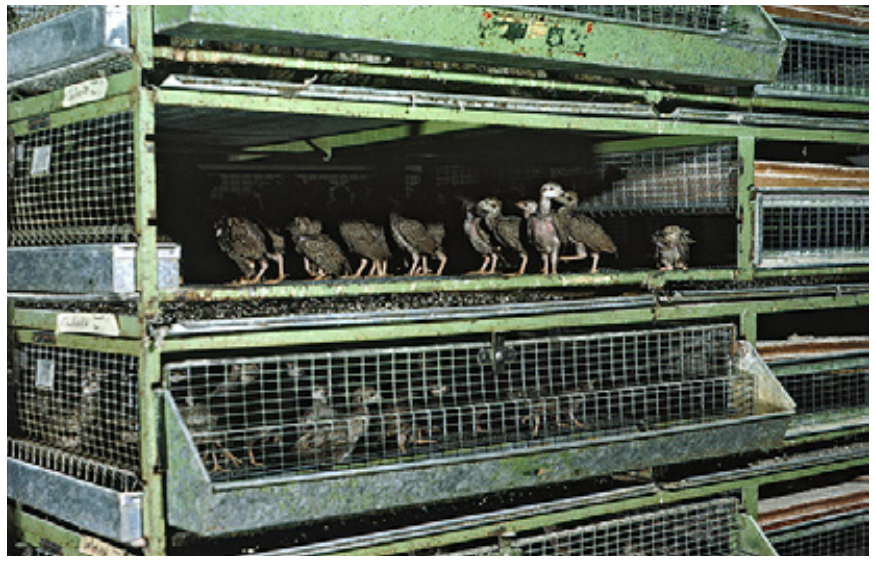

Figure 6. Battery brooding chukar partridge chicks. wet litter in the pen, ventilation is marginal or inadequate. Fans and uniform-slot air intakes provide good ventilation in a house with high bird density. Ventilation should be designed to mix colder incoming with warmer inside air before it reaches the chicks' level.

\section{Brooding Methods}

Battery brooding has attractive features for some growers. Batteries are particularly well suited to small groups of chicks that need to be raised separately (fig. 6). The battery units are easy to clean and the chicks are easy to inspect. With a larger hatch, battery brooding requires more labor than floor brooding, and battery-brooded pheasant or partridge chicks must be moved to other pens when they grow too tall for the space.

\section{Preparing the Brooder}

For floor brooding, your first step in preparing a pen for new chicks is to clean the area thoroughly, including the walls, ceilings, and all equipment that will be used in the brooding pen. Then apply a disinfectant to the brooding area and the equipment.

After the pen is disinfected and thoroughly dry, place 3 or 4 inches of clean litter in the pen. Soft wood shavings, peanut hulls, rice hulls, sugar cane fiber, ground corn cobs, or chopped straw are useful litter materials. Sawdust and sand, although sometimes used, are less desirable. Litter should be free of molds and toxic materials. Some growers cover the litter with rough brooding paper during the first few days of brooding. This is particularly recommended for small chicks such as quail. The paper keeps chicks from eating litter, and you can put their feed on the paper at first to help get them to eat (see figs. 4 and 5). Most early losses result from the chicks' failure to find feed or water.

Now place the heating unit in position. A brooder ring 15 to 20 inches (37.5 to $50 \mathrm{~cm})$ high and made of corrugated cardboard or 1/2-inch $(1.25 \mathrm{~cm})$ mesh hardware cloth should be placed around the heat stove to form a circle approximately 18 inches $(45 \mathrm{~cm})$ from the edge of the stove. (Quail require a finer-mesh hardware cloth.) This ring will keep the chicks close to the heat source. The solid corrugated cardboard ring is preferable to hardware cloth because it also protects the chicks from drafts.

Start the stove and adjust it to the correct temperature at least 1 day before chicks are to be placed under the heating unit. Place feed troughs and water fountains in the brooder ring and fill them before chicks arrive. Allow at least 20 inches (50 $\mathrm{cm}$ ) of eating space per 100 chicks. Some feed should also be placed on the floor in egg flats, box covers, or plastic trays during the first 3 to 5 days to encourage chicks to eat.

Make sure to provide plenty of drinking space-at least two 1-gallon (3.78 liter) fountains per 100 chicks_-so that chicks will be able to find water quickly. Use watering devices of the right size so the chicks will not be able to fall into the water reservoir. Special small-sized plastic quail fountains are available and are the best choice if you are raising quail. If you cannot find these, you may have to cover the water trough with hardware cloth or place pebbles in the trough to keep the chicks from getting their down wet (resulting in chilling) or drowning in the fountain. Most healthy chicks that die during the first week do so because they fail to learn to drink. It is a good practice to dip the beak of each chick into the water as you remove it from the box and place it in the pen. 

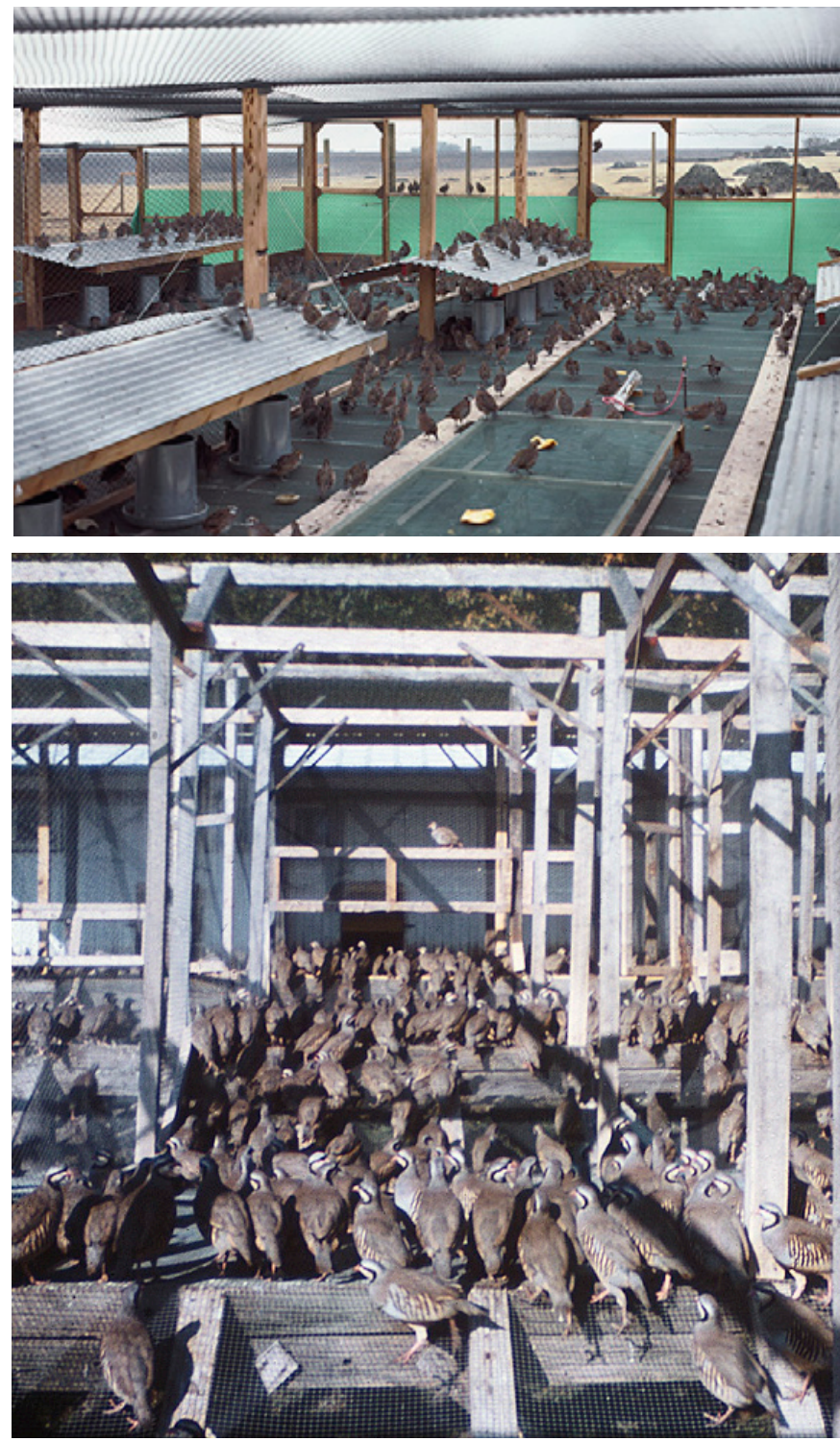

Figure 7. Two types of wire-floor pens used for quail and partridge.
Always check young chicks after dark (with the lights off) to be certain that none are huddled away from the heat. Chicks that settle away from the heat will become chilled and those on the outside of the huddle will crowd toward the center, causing chicks in the center of the group to smother before morning. Move any that are huddle away from the heat back under the brooder. An attraction light under the stove can help keep chicks under the stove at night.

\section{GROWING GAME BIRDS}

The basic principles and techniques for growing domestic poultry also apply to most game bird species. The successful breeder modifies those practices to fit the needs of each type of game bird.

\section{Cages and Pens}

You can grow chukars and quail successfully in all-wire cages or wire-floor pens. About 1 square foot $(0.023$ square meter) per bird is adequate for chukars and $1 / 2$ square foot (0.046 square meter) for quail (fig. 7).

If you build outdoor pens for growing or holding breeding stock, make sure to construct them in a way that permits good drainage of water from sprinklers or storms. Pens for growing birds may be of various sizes, but their actual construction remains generally the same. Pens used in large commercial production usually are arranged side by side with the ends opening into a central service aisle that is covered to prevent the birds' escape. The support posts are often $4 \times 4$ $(9 \times 9 \mathrm{~cm})$ redwood or treated wood posts on 8 - or 10 -foot (2.4 or 3.0 meter) centers. Some builders alternate $2 \times 4(3.8 \times 9 \mathrm{~cm})$ support posts with the $4 \times 4$ $(9 \times 9 \mathrm{~cm})$ posts. Both metal and plastic posts are also used successfully.

To provide protection from the wind, the lower wall of an outdoor pen should be boarded to a height of 20 or 24 inches $(50$ or $60 \mathrm{~cm}$ ). Make the outside perimeter predator- and rodent-proof by burying a piece of wire netting 12 inches $(30 \mathrm{~cm})$ wide to a depth of 8 inches $(20 \mathrm{~cm})$ with the remaining 4 inches

Table 4. Suggested pen size and bird density

\begin{tabular}{|c|c|c|c|}
\hline \multirow[b]{2}{*}{ Species } & \multicolumn{3}{|c|}{ Pen size } \\
\hline & $\begin{array}{c}\text { Width } \\
\mathrm{ft}\end{array}$ & $\begin{array}{c}\text { Length } \\
\mathrm{ft}\end{array}$ & $\begin{array}{l}\text { Bird density } \\
\text { sq ft/bird }\end{array}$ \\
\hline \multirow[t]{2}{*}{ Chukar } & 50 or 100 & 150 & 3 to 5 \\
\hline & (15 or $30 \mathrm{~m})$ & $(45 \mathrm{~m})$ & ( 0.28 to $0.46 \mathrm{sq} \mathrm{m})$ \\
\hline \multirow[t]{2}{*}{ Pheasant } & 50 or 100 & 150 & 10 to $12^{*}$ \\
\hline & $(15$ or $30 \mathrm{~m})$ & $(45 \mathrm{~m})$ & (0.93 to $1.11 \mathrm{sq} \mathrm{m}$ ) \\
\hline \multirow[t]{2}{*}{ Quail } & 50 & 150 & 3 to 4 \\
\hline & $(15 \mathrm{~m})$ & $(45 \mathrm{~m})$ & ( 0.28 to $0.37 \mathrm{sq} \mathrm{m})$ \\
\hline
\end{tabular}

*Double the space required for each species if growing pens do not have adequate vegetative cover.
$(10 \mathrm{~cm})$ turned outward. The sides of the pens, whether interior partitions (between pens) or exterior walls, are commonly covered with 1- or 2-inch (52.6 or $5.2 \mathrm{~cm}$ ) wire mesh (poultry netting). The tops are usually enclosed with 2-inch woven plastic fabric (figs. 8, 10, and 11).

Commercial game bird growers use pens of various dimensions, usually from 50 to 100 feet wide and 100 to 300 feet long (approx. 15 to $30 \mathrm{~m}$ wide and 30 to $90 \mathrm{~m}$ long). The number of birds put into the pen depends on the pen size and the ground cover (vegetation) available. Twice as many birds can be grown in pens with adequate ground cover as in pens without any ground cover (see table 4). 


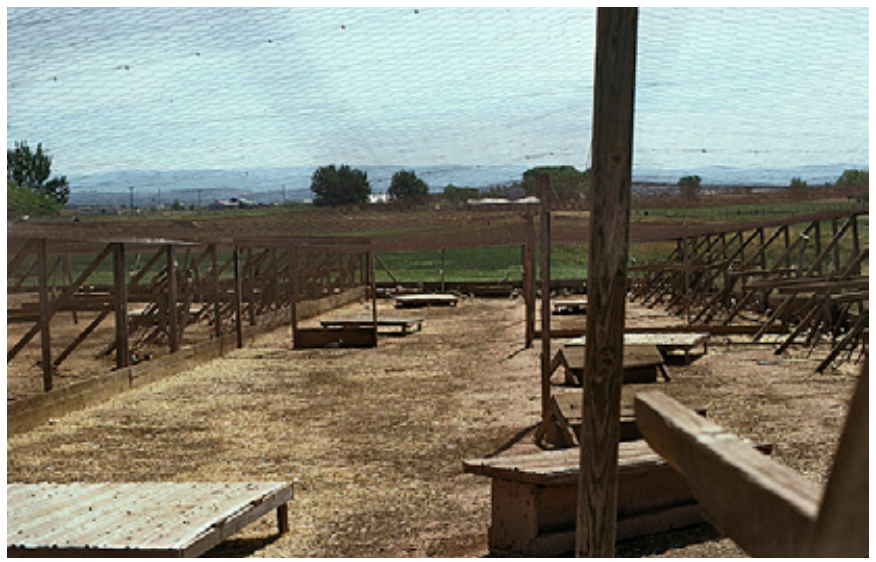

Figure 8. Flight pen showing footer board, nests, and escape shelters.

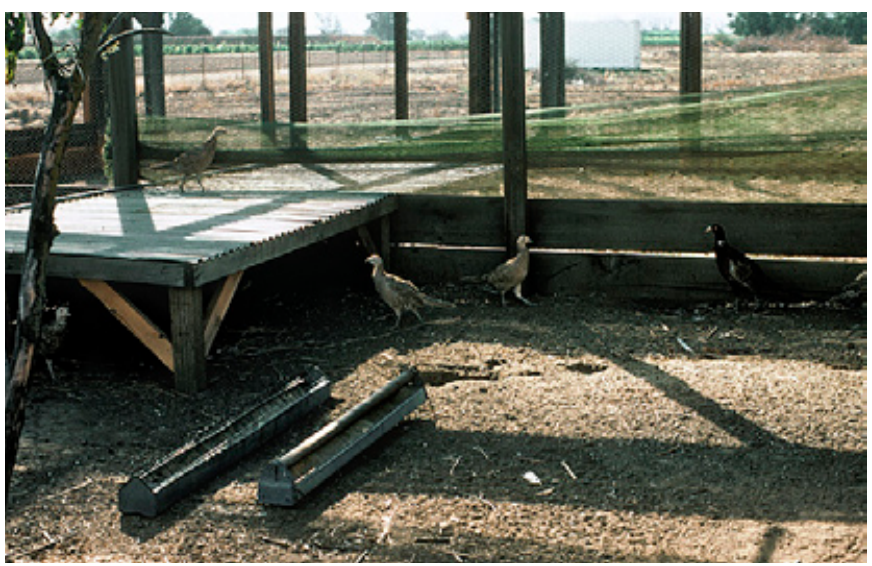

Figure 9. Small pen used for propagation of exotic species.

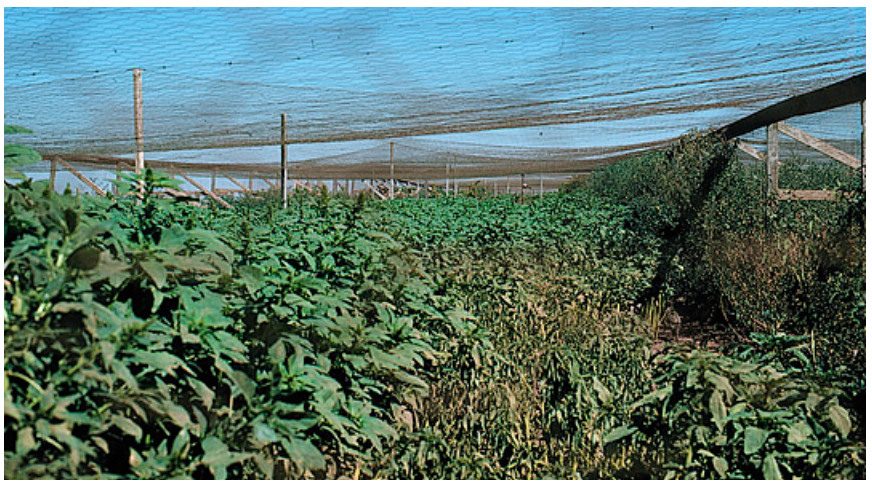

Figure 10. Flight pen with a dense cover crop of volunteer plants.

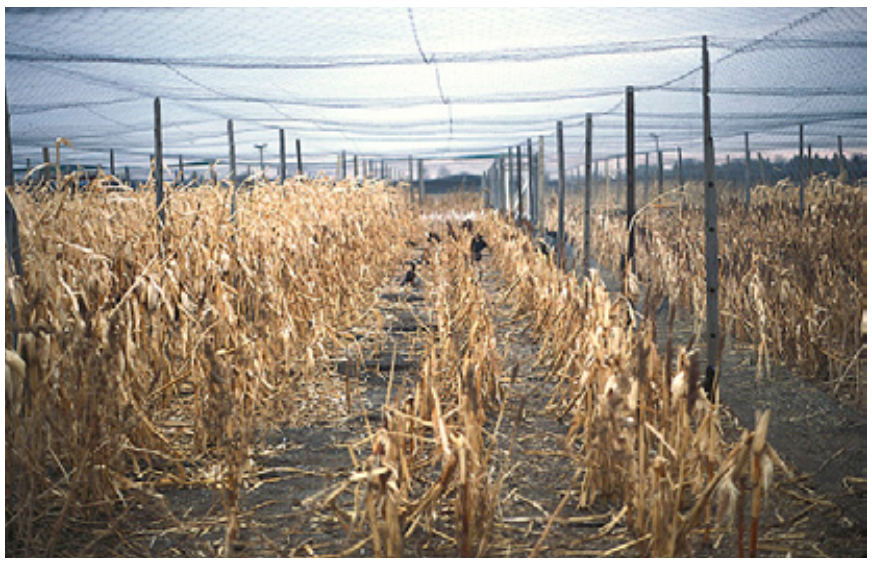

Figure 11. Flight pen with a good cover crop of field corn.
The space requirements for growing ornamental pheasants are greater than for other pheasants on account of their timid behavior and elaborate feathering (fig. 9). More protection is usually provided for exotic pheasants such as fireback, argus, peacock, and longtailed pheasants.

\section{Cover Crops}

Cover crops grown in rearing pens offer shade, shelter, environmental enrichment, food, and opportunities for escape from picking by other birds (figs. 10 and 11). The crop that you choose will depend on your game bird species, climate, season of use, and the availability of irrigation or rainwater. Many plants provide useful cover, but spring annual plants that grow rapidly to heights of 4 feet or more are popular. Some that are often used for pheasant pens are lambsquarter, millet, corn, oats, wheat, barley, mustard, vetch, and rape. Often if the cover is dense when the birds are introduced, rows are cut through the cover to provide easier access for birds and caretakers.

\section{Water Fountains and Feeders}

Water fountains must provide a continuous supply of fresh, cool drinking water. Float pans, bowl fountains, and plastic dome fountains are popular types used on commercial game farms (fig. 12). It is best to have a screened platform or dry well filled with rock beneath each fountain to prevent puddles and mud.

Feeders of many designs are used successfully on game farms. The size and type depend on the farming operation. A good management practice is to keep all feeds covered. Many range feeders are designed with a sloping cover that keeps the feed dry during bad weather (fig. 13). Open-trough feeders can be used for grit and oyster shell.

\section{MANAGEMENT OF BREEDING STOCK}

In order to establish a good foundation stock, it is important that you get your original eggs or stock from a Salmonella pullorum-free source. The potential breeder stock should be free of abnormalities (blindness, crooked toes, or malformed beak, neck, or leg bones). The birds should have good body conformation and exhibit a size and color pattern that are characteristic of the species or that are desired by you, the game bird breeder.

\section{Cages and Pens}

Breeding pheasants perform satisfactorily when housed in wire colony cages. A mating ratio of ten pheasant hens to one cock is recommended in a colony pen mea- 

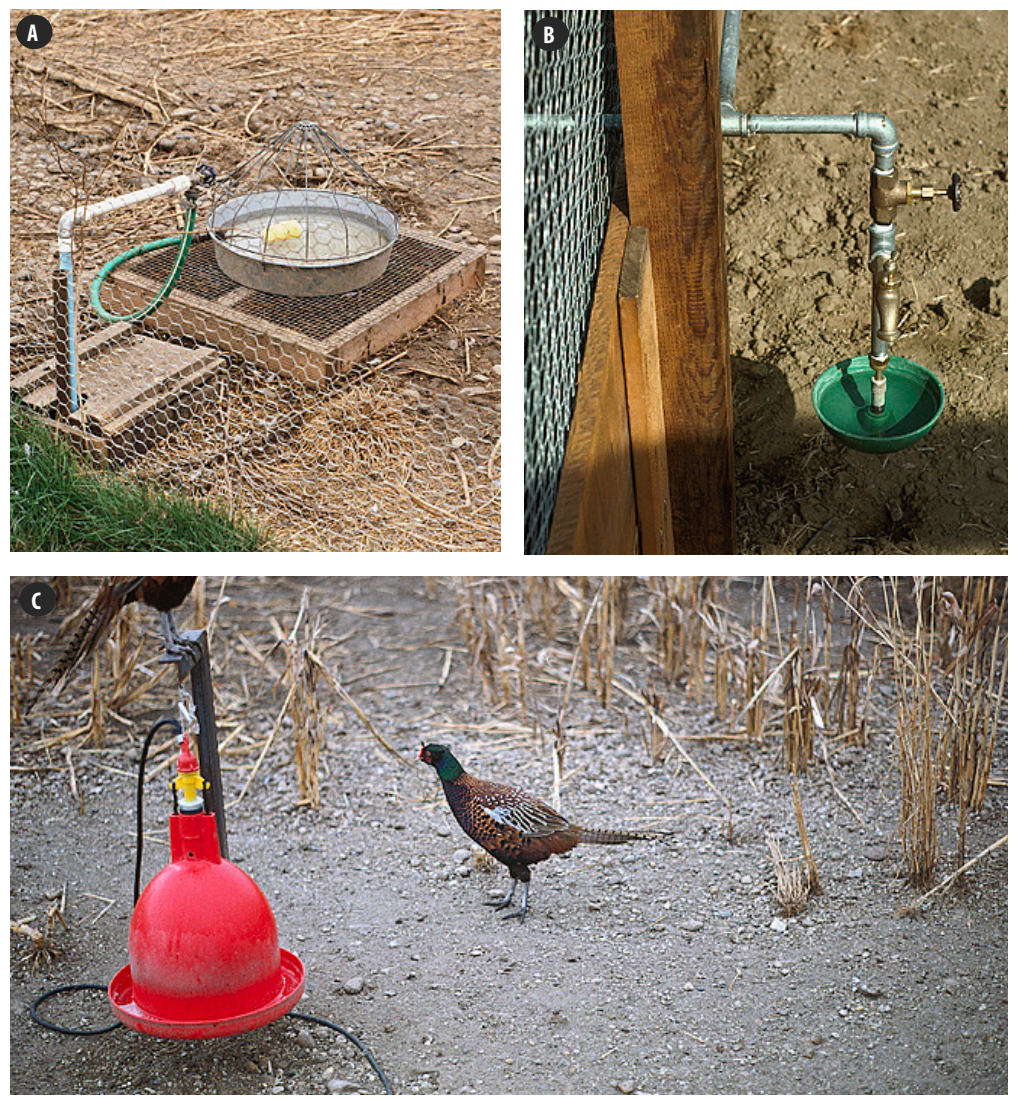

Figure 12. Three types of water fountain used in flight pens.

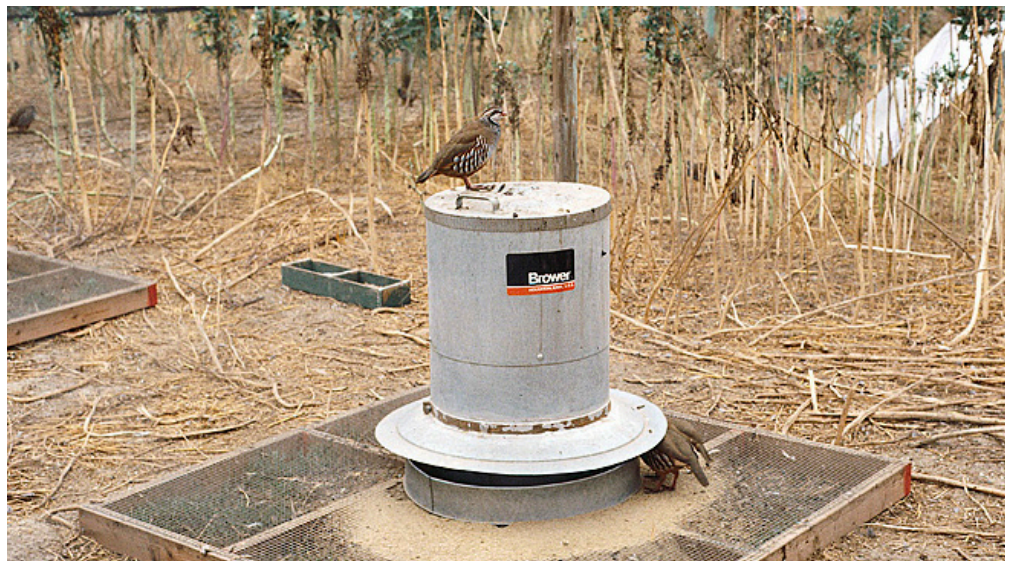

Figure 13. Range feeder with metal rain shield and wire platform.

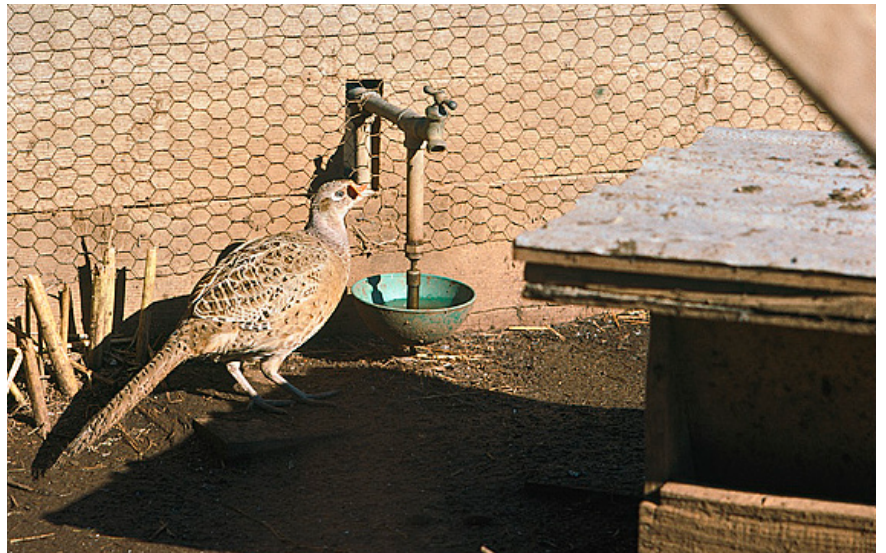

Figure 14. Pheasant nest box with metal roof for use in an outdoor breeder pen. suring 2 feet $(0.6 \mathrm{~m})$ wide by 6 feet $(1.8 \mathrm{~m})$ long by $1 \frac{1}{2}$ feet $(0.45 \mathrm{~m})$ high.

Range pens that are similar to those used for growing birds can also be used for breeders. A good rule of thumb is to maintain about 25 to 30 square feet ( 2.3 to $2.8 \mathrm{sq} \mathrm{m}$ ) per bird. The pen can be seeded with a cover crop to provide cover for the breeding stock.

\section{Equipment}

The same types of feeders and water fountains that you use in the growing pens can be used for the breeders. Make sure that your feeders have adequate rain covers.

Covered nest boxes placed in protected areas within the pen greatly reduce the incidence of dirty eggs and prevent bacterial contamination (fig. 14). A wooden nest box 2 feet $(0.6 \mathrm{~m})$ wide, 6 feet $(1.8 \mathrm{~m})$ long, and 1 foot $(0.3 \mathrm{~m})$ tall, either subdivided into three compartments or constructed as a single walk-through unit, will serve about 24 hens (fig. 15). Place the nest boxes in breeding pens well in advance of the laying season in order to encourage the hens to use them rather than lay their eggs on the ground. Darken the net boxes by providing a curtain over the entrance. You can also place low shelters in pens to serve as rain shelters, sun shades, and escape sites for hens chased by over-aggressive males (see fig. 8).

\section{Care of Eggs}

Proper handling and care of eggs are extremely important in maintaining their hatchability. Store hatching eggs in a cool room maintained at about $50^{\circ}$ to $60^{\circ} \mathrm{F}\left(10^{\circ}\right.$ to $\left.15.6^{\circ} \mathrm{C}\right)$ and 70 percent relative humidity (see table 1 ). 


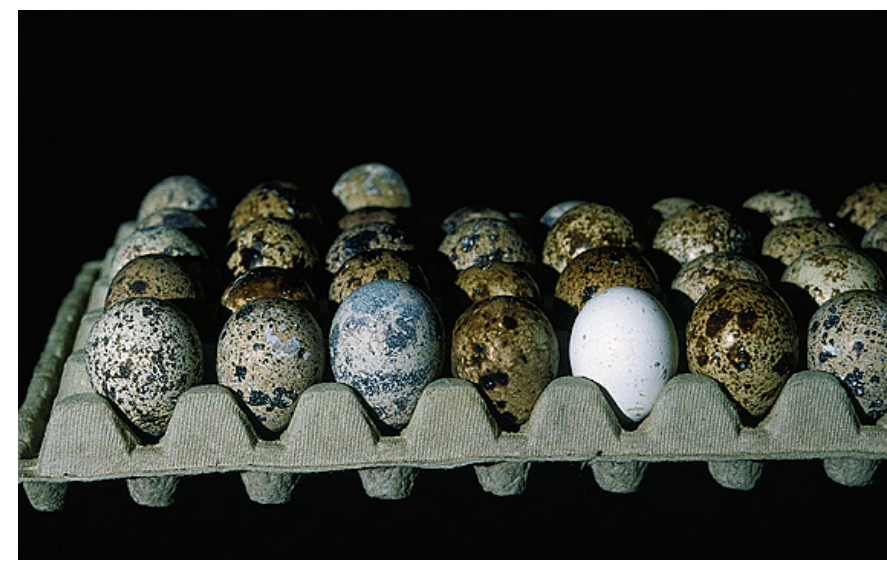

Figure 16. Clean Japanese quail eggs stored in an appropriate-sized egg flat.

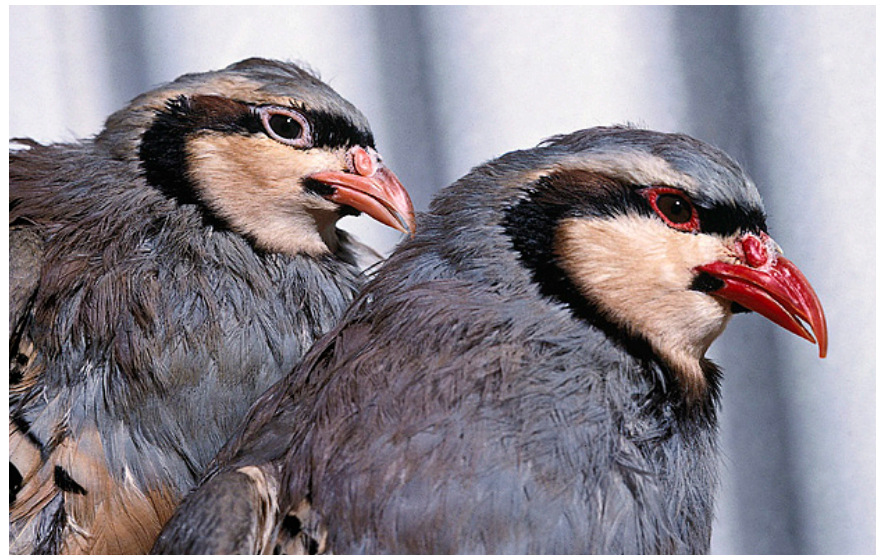

Figure 17. Comparison of sexually mature female (left) and male (right) chukars.

Following are recommendations for the proper care of hatching eggs:

- Keep nest areas clean and dry.

- Use clean nest litter and replace it as necessary.

- Collect eggs at least three times daily and separate out any dirty eggs.

- Clean and/or sanitize eggs after collection.

- When gathering eggs, avoid overfilling the basket.

- Do not spray insecticides around breeder pens or the egg holding room.

- If any eggs have slightly soiled shells, clean them with a light abrasive (sandpaper) material and sanitize them soon after gathering. Do not use heavily soiled eggs for hatching.

Eggs that are to be set within 14 days of collection should be stored large-endup in open egg flats or clean egg cases (fig. 16). Eggs to be held longer than 14 days should be placed in flats, sealed in new plastic bags after a 24-hour cool down, and turned at least twice per day.

\section{Sexing Chukar Partridges}

The sex of chuckars is difficult to determine from the birds' appearance. Both sexes have spurs and virtually identical plumage. Males are slightly larger and an experienced grower can separate sexes with reasonable accuracy (fig. 17). An alternative sexing method known as "day-old vent sexing" is quite accurate and is described in detail by Siopes and Wilson (1973).

\section{Lighting}

Game birds of an appropriate age can be induced to lay at any time of the year provided they have been exposed to day-lengths of less than 12 hours for a minimum of 6 weeks before they are given a stimulatory day-length (13 hours per day or longer). A series of lamps placed above the breeder pens or pole-mounted outdoor lamps can furnish the light necessary to stimulate early egg production. Most lamps (including incandescent, fluorescent, quartz, and sodium vapor lamps) provide light of an appropriate wavelength to stimulate egg laying and semen production in game birds. You can use a programmable timer switch to control the timing and duration of the light period. 


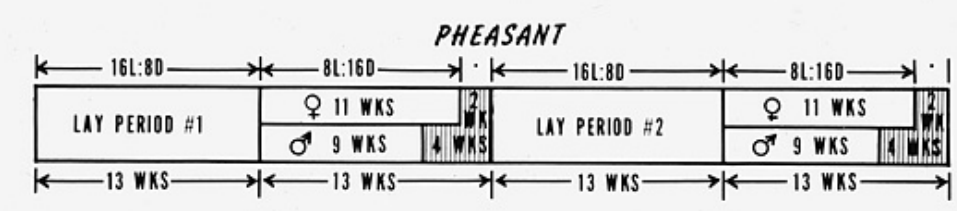

PARTRIDGE

\begin{tabular}{|c|c|c|c|c|}
\hline \multicolumn{2}{|c|}{$-16 \mathrm{~L}: 80 \longrightarrow \mathrm{L}-8 \mathrm{~L}: 160 \rightarrow+1}$. & $\leftarrow 161: 80-$ & \multicolumn{2}{|c|}{$k \leftarrow 8 \mathrm{BL}: 160 \longrightarrow \mathrm{K} \leftarrow 16 \mathrm{16}: 80 \longrightarrow$} \\
\hline & 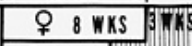 & & \begin{tabular}{|l|l|l|} 
ㅇ $8 \mathrm{wkS}$ & $3 \mathrm{wkS}$ \\
\end{tabular} & \\
\hline LAY PERIOO \#1 & 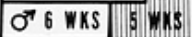 & LAT PERIO0 \#2 & \begin{tabular}{|l|l|}
$O^{\prime \prime} 6$ WKS & $5 \mathrm{WKS}$ \\
\end{tabular} & LAY PERIOD \#3 \\
\hline
\end{tabular}

Figure 18. Suggested lighting schedule for recycling pheasant and partridge breeders.
Pheasant, partridge, and turkey hens become refractory (non-responsive) to long day-lengths (13 hours or more) after several weeks of egg production. The duration of an egg production cycle varies with species and the pen or house environment. To recycle hens so they will lay again, start after the breeding season by restricting their light to 8 hours per day. Eight weeks later, start exposing the birds to a stimulatory light regime of 14 or more hours per day. Hens begin to lay about 18 to 21 days after the start of stimulatory light. Always light males 2 weeks before you light females to ensure good early fertility, since males respond more slowly to a stimulatory light regime (fig. 18). While a laying period of 13 weeks' duration is suggested for pheasants, you can actually continue egg production until production and fertility drop to levels you consider unacceptable. When you opt for restricted daylengths, you are necessarily opting for confined housing with light control. Before you make this choice, remember that experience has shown the duration of egg production to be longer under outdoor conditions.

\section{FEEDING GAME BIRDS}

Game bird feed can come in the form of mash, crumbles, or pellets. Pellets and crumbles are made from mash and may be more expensive. There is little advantage in feeding pelleted diets to game birds. Game birds thrive on any game bird or poultry diet that is properly balanced in metabolizable energy, amino acids, vitamins, and minerals. Suggested protein levels for game bird feeds are shown in table 5.

Never feed laying rations to day-old game birds. A laying ration contains a high level of calcium, which can be harmful to growing chicks. Also, do not feed whole grain to day-old chicks. Breeders sometimes feed cracked grain to game bird chicks on the first day after hatching to reduce vent pasting problems. After the birds are about 4 weeks old, you can use whole grain for part of the diet if you also make grit available.

The simplest way to feed game birds is to buy a game bird or turkey starter ration that contains 24 to 28 percent protein and to feed the chicks on that for the first 6 weeks. From 7 to 14 weeks of age, feed them on a game bird or turkey grower diet or a chicken starter diet that contains about 20 percent protein. From 15 weeks of age until market, feed them with a game bird, chicken, or turkey growing diet that

Table 5. Recommended total protein levels for game birds, as a percentage of the diet

\begin{tabular}{|c|c|c|c|c|c|}
\hline \multirow[b]{2}{*}{ Species } & $\begin{array}{l}\text { Starting } \\
(0-6 \text { wks })\end{array}$ & $\begin{array}{c}\text { Grower } 1 \\
\text { (7-14 wks) }\end{array}$ & $\begin{array}{c}\text { Grower } 2 \\
\text { (15-20 wks) }\end{array}$ & $\begin{array}{c}\text { Holding } \\
(21-30+\text { wks })\end{array}$ & Breeding $^{1}$ \\
\hline & \multicolumn{5}{|c|}{$\%$} \\
\hline Chukar partridge & 25 & 20 & 15 & 14 & 18 \\
\hline Pheasant & $24-28$ & 18 & 15 & 14 & $15-18$ \\
\hline Bobwhite quail & 26 & 20 & 15 & 14 & 24 \\
\hline Japanese quail & 24 & mature at 6 wks & mature at 6 wks & $14^{2}$ & 20 \\
\hline
\end{tabular}


Table 6. Growth rate and feed consumption of some game birds (mixed sexes)*

\begin{tabular}{|c|c|c|c|c|c|c|}
\hline \multirow[b]{2}{*}{ Age } & \multicolumn{2}{|c|}{ Ring-necked pheasant } & \multicolumn{2}{|c|}{ Chukar partridge } & \multicolumn{2}{|c|}{ Japanese quail } \\
\hline & $\begin{array}{c}\text { Cumulative } \\
\text { weight }\end{array}$ & $\begin{array}{l}\text { Cumulative } \\
\text { feed consumed }\end{array}$ & $\begin{array}{c}\text { Cumulative } \\
\text { weight }\end{array}$ & $\begin{array}{l}\text { Cumulative } \\
\text { feed consumed }\end{array}$ & $\begin{array}{c}\text { Cumulative } \\
\text { weight }\end{array}$ & $\begin{array}{c}\text { Cumulative } \\
\text { feed consumed }\end{array}$ \\
\hline weeks & & & gm & & & \\
\hline 1 & 41 & 59 & 32 & 32 & 23 & 32 \\
\hline 2 & 82 & 154 & 54 & 90 & 45 & 65 \\
\hline 3 & 136 & 286 & 100 & 220 & 73 & 114 \\
\hline 4 & 195 & 450 & 159 & 368 & 95 & 180 \\
\hline 5 & 264 & 614 & 210 & 527 & 109 & 255 \\
\hline 6 & 350 & 865 & 250 & 730 & 118 & 335 \\
\hline 7 & 436 & 1,160 & 320 & 970 & 127 & 445 \\
\hline 8 & 523 & 1,455 & 370 & 1,200 & 132 & 570 \\
\hline 9 & 591 & 1,750 & 405 & 1,430 & 136 & 715 \\
\hline 10 & 690 & 2,090 & 435 & 1,660 & 136 & 950 \\
\hline 11 & 775 & 2,520 & 480 & 1,910 & 136 & 1,020 \\
\hline 12 & 840 & 2,955 & 515 & 2,200 & 141 & 1,195 \\
\hline 13 & 920 & 3,385 & 527 & 2,490 & 141 & 1,365 \\
\hline 14 & 1,000 & 3,860 & 545 & 2,720 & 145 & 1,480 \\
\hline 15 & 1,065 & 4,320 & 550 & 2,945 & 145 & 1,605 \\
\hline 16 & 1,100 & 4,820 & 568 & 3,135 & 145 & 1,735 \\
\hline 17 & 1,135 & 5,320 & 577 & 3,325 & 150 & 1,865 \\
\hline 18 & 1,140 & 5,820 & 590 & 3,520 & 150 & 2,020 \\
\hline
\end{tabular}

contains about 15 percent dietary protein. When fed such diets, most game birds grow at the rates shown in table 6 .

You can use a turkey starter mash with 28 percent protein as a diet for small flocks of game birds if you feed according to the schedule shown in table 7. Breeding birds need a good breeder ration with about 15 to 16 percent protein.

Place grit and mash in separate containers. The size of grit you will want to provide depends upon the size of the bird. The grit should be insoluble in dilute hydrochloric acid. Fine gravel is an acceptable substitute for purchased grit.

Do not store feed for more than 6 weeks at any time, especially in the summer. Protect the feed from rodents and insects. We suggest storing small amounts of feed in metal or plastic garbage cans with tight-fitting lids. Growers of large flocks will need bulk feed tanks. Keep feeders and feed tanks clean and dry to prevent any mold growth.

\section{Vitamin Supplements}

No additional vitamin supplement is required if you feed the birds daily with a fresh, high-quality diet of appropriate nutrient content. Unfortunately, growers often store diets too long and as a result vitamin deficiencies are often seen in game birds, especially during the hatching season. Unless you are certain that your birds' feed is fresh, complete, and of the highest quality, we strongly recommend that you add vitamin supplements to their water supply. You can get this type of vitamin supplement from feed stores and many animal drug suppliers. Supplementation will provide effective protection against possible vitamin deficiencies. Breeding hens must have adequate vitamin levels 3 weeks before the first egg is laid.

\section{DISEASE CONTROL}

Diseases constitute a serious threat to any game bird operation. Most diseases affecting game birds are caused by microorganisms or viruses spread from bird to bird, whether directly or indirectly. People spread disease agents in many ways, but mainly 
by moving live birds, manure, contaminated equipment, or the caretaker's contaminated clothing or footwear from one bird area to another. Follow these management practices to prevent introduction of disease agents to your farm:

1. Avoid introducing live birds. Live birds are a principal means of bringing disease organisms to susceptible birds. Even though an introduced bird may appear perfectly healthy, it may be a disease carrier. A carrier is infected and can carry disease agents to uninfected birds without showing any clinical signs of disease itself. If you have to introduce new stock, the safest way is to buy hatching eggs or day-old baby chicks.

2. Buy chicks from known, trusted sources. Some diseases can be passed from parent to chick through the egg. You can avoid these diseases by purchasing day-old chicks from a breeder with a reputation for producing disease-free stock.

3. Separate age groups. Older birds may be infected with agents that do not cause clinical disease, but the same agent may cause a high rate of mortality in young chicks. Under ideal conditions, you would raise each species of game bird separately to eliminate the possibility of disease or parasite problems. When you are unable to avoid raising two or more age groups on the same premises, separate the groups by as great a distance as is possible. During the work day, care for the youngest birds first. Chicks are more susceptible to diseases than older birds. Keep dedicated footwear and coveralls at the entrance to each brooding area and insist that all caretakers wear these when caring for the birds.

4. Establish an entry station where you clean and disinfect equipment entering the farm.

5. Control access to your game bird farm. People and service vehicles such as feed delivery trucks may carry infectious agents. Stop them at your gate and make sure that they are clean before you let them enter. It is a good idea to disinfect the vehicle's wheels and undercarriage at this point by applying a disinfectant.

6. Require that clean visitors wear coveralls, foot coverings, and head coverings provided by you. Don't allow visitors who have been in contact with any birds during the previous 24 hours, and make sure they have showered and changed all clothing since their most recent bird visit.

Do not visit other poultry farms unless it is simply unavoidable. If you do visit, wear protective clothing and then leave that clothing at the farm when you leave, then shower and change all clothing and footwear before you return to your bird pens. Other places to avoid are waterfowl areas, feed stores, zoos, and any area where you may contact birds or their droppings.

\section{Dead Bird Disposal}

You will need a way to dispose of dead birds that prevents the spread of pathogens to surviving birds. Your disposal method should also result in the appropriate recycling of nutrients to the soil without contaminating surface or ground water. The following methods are appropriate under all soil and water conditions:

Rendering is an acceptable method from an environmental standpoint, but it may expose the farm to pathogens if you fail to take proper precautions to keep the renderer's truck away from your bird growing pens. The rendering pick-up area should be at the road entrance to your farm and should be neat and screened from public view. Rendering is a flexible option in that it can accommodate a sudden increase in mortality. Containers for storing dead birds until the renderers arrive must be fly-tight and pick-up should be scheduled at least twice weekly unless you are able to hold the dead birds in refrigerated storage. 
Composting the carcasses with litter, if properly done, is an acceptable disposal method and results in a valuable compost by-product that makes an excellent soil amendment. Do the composting on a concrete pad to prevent leaching and under a roof to prevent excessive wetting of the compost. The composting process must be managed to ensure that the material reaches a high enough temperature to destroy pathogens. This system is flexible and, like rendering, can handle a sudden increase in mortality.

Incineration is a sanitary disposal method. The incinerator unit must meet local air pollution standards. Incinerators require energy input and are of a fixed capacity, so they cannot handle a sudden increase in mortality. The ash from incineration is a useful fertilizer material, but you must dispose of it properly in order to avoid pollution problems.

Disposal pits or burial are environmentally acceptable solutions in soils where the movement of nitrogen into groundwater will not cause a problem. Unfortunately, it may cost as much to determine the suitability of a particular site for pit disposal or burial as it would cost to construct a suitable composter, and there is no guarantee that the area will be suitable. Pits work best with a constant load of mortality and do not handle sudden increases in mortality well, while burial can usually handle any quantity of carcasses. Fly maggots have been known to emerge from carcasses buried 5 feet $(1.5 \mathrm{~m})$ deep in loose soils, and fly maggots are often a source of botulism toxin. One maggot may carry enough toxin to kill an adult game bird.

\section{Dealing with a Disease Outbreak}

If an unusually high number of birds die unexpectedly and the surviving birds seem unhealthy, take immediate action by isolating the pens with sick birds and stopping all movement of live or dead birds, manure, and equipment. Anyone who visits the sick pen must clean and disinfect his or her footwear and change his or her clothing after leaving the pen. Send a representative sample of sick live birds as well as some dead birds to the diagnostic laboratory closest to you. Details about laboratory submission in California are available online at http://cahfs.ucdavis.edu. Most laboratories charge a fee for the examination.

Treat sick birds as directed by a veterinarian. In acute outbreaks of disease, it is more effective to administer medication in drinking water than in feed, since sick birds often will drink even if they will not eat.

\section{Vaccination}

There is no general rule for vaccination of game birds. Talk with an experienced avian veterinarian in your area to find out which diseases are prevalent there and which vaccinations you should give your birds.

\section{Other Recommendations for Sanitation}

Preventive disease control is a crucial part of a successful game bird program. You can avoid many problems if you follow certain management practices:

- Maintain a good biosecurity program and train employees to ensure its success.

- Thoroughly clean and disinfect all equipment and housing between groups of birds.

- Control predators and rodents, as they may be carriers of disease and external parasites.

- Establish a relationship with a good avian veterinarian who can assist you in disease prevention planning and provide support if any disease problem occurs. 


\section{SOME COMMON DISEASE PROBLEMS}

\section{Parasitic Diseases}

Coccidiosis is a destructive protozoan disease that can occur in all game bird species. It is predominantly a disease of young chicks and is characterized by symptoms of weakness, ruffled feathers, and unthriftiness. Droppings may be bloody. Affected birds are listless and show little interest in feed or water. As the disease advances, you can expect moderate to high mortality in the flock. Maintain dry litter and use a good coccidiostat in the feed or water to both prevent the disease and encourage the development of immunity in young growing chicks.

Blackhead is a destructive protozoan disease of pheasants, chukars, and grouse. It may spread directly through contact with contaminated feces or indirectly through the infected egg of the cecal worm Heterakis. The Blackhead protozoan can remain infective even on farms left empty for many years. Chickens may harbor the agent without showing clinical disease symptoms, so you should not raise chickens with susceptible species. Infected birds appear droopy, stop feeding, and have a yellowish brown stool that is watery and foamy. Acutely involved chukars may die very quickly, before they even show any outward symptoms.

Worms are often found in game birds at necropsy. Earthworms, slugs, snails, beetles, and other insects are involved in the spread of many parasitic diseases. The best protection against worms is to avoid wet spots around waterers and feeders and to provide well-drained, sloping pens.

\section{Acute Infectious Diseases}

Erysipelas is a bacterial disease that occurs most often in adult pheasants during the fall. Most affected birds are visibly sick for only a short period before death, so you may not even see symptoms before they die. General symptoms include weakness, listlessness, loss of appetite, and sometimes a yellowish or greenish diarrhea. Avoid the use of areas previously occupied by swine, sheep, or turkeys.

Fowl cholera generally strikes mature birds late in winter or spring and can cause very high death loss. It can be introduced onto the farm by wild birds, rodents, and other animals. Treatment consists of the prompt removal of dead birds and the use of antibiotics once a diagnosis has been made.

\section{Viral Diseases}

When exposure to the following viruses is likely-for example, in areas with high poultry populations-vaccination is recommended. It is advisable to consult a veterinarian when planning a vaccination program.

Newcastle disease is a very contagious viral disease of avian species, including most game birds. The virus that causes Newcastle disease can either cause a mild or a severe form of the disease. The mild form is characterized by coughing and followed by degrees of leg and wing paralysis, tremors, and twisting of the neck. Symptoms of the mild form can be prevented by vaccination. The severe form of Newcastle disease, "Exotic Newcastle disease," will cause sudden high mortality. There is no vaccine that can provide flocks with complete protection from Exotic Newcastle disease symptoms and mortality. Detection of the exotic form of Newcastle disease in your game bird population will result in a government disease control program.

Marble spleen disease is a viral disease commonly found in pen-raised pheasants and is characterized by deaths with or without noticeable signs of illness. The most consistent internal symptoms are severe edema (fluid in tissues), an enlarged, grayishtan, mottled spleen, and inflammation of the lungs. Vaccination can prevent bird loss. 
Quail bronchitis is a severe respiratory disease affecting quail and caused by a virus. The disease, which affects young quail, is characterized by rapidly spreading respiratory signs (wheezing, coughing, and sneezing) and mortality rates ranging from 10 to 100 percent over a period of several weeks. There is no vaccine for this disease and it can only be prevented with biosecurity.

Fowl pox is a viral infection affecting most game birds and characterized by many crusty scabs on the skin and mucous membranes of the mouth and upper respiratory tract. It is spread by mosquitoes and other biting insects. Prevention is the best approach to control of this disease, and that can be achieved with mosquito control. Once birds in an area are infected with fowl pox or the farm experiences chronic problems, you should start vaccinating.

Avian influenza is a serious disease of poultry and game birds that is often carried by wild waterfowl. Like Newcastle disease, Avian influenza has a mild form that is usually characterized by respiratory systems or decreased egg production in breeders. Forms of the avian influenza virus isolated from birds vary widely in their pathogenicity. Mortality can range from zero to 100 percent. When diagnosed by a laboratory, avian influenza must be reported to state and federal animal health authorities. Isolates are typed and if they are determined to be "high-pathogenicity types" the government will institute a disease control program.

\section{CONTROL OF CANNIBALISM}

Cannibalism occurs frequently among game birds kept in captivity. This vicious habit may start as a mild form of feather or toe picking and develop into a full-scale attack on the flesh of other birds. Game birds of all types and ages are subject to outbreaks of cannibalism. Pheasants are more prone to cannibalism than other species of game bird. Some factors contributing to cannibalism include

- Overcrowding. High-density housing brings the birds into close contact with one another. Picking may start as a result of boredom, idleness, and lack of adequate feeder space.

- Improper temperature. Too high a brooding temperature may cause birds to become irate and pick at one another.

- Light. Bright brooder lights increase activity and picking. Less picking occurs when chicks are brooded under natural daylight or artificial light of low intensity (1 to 2 foot-candles at the feed troughs).

- Age. Cannibalism occurs in all age groups. Toe, beak, and feather picking are more common among baby chicks, whereas vent, wing, and head picking are usually found in older birds.

- Sanitation. Poor brooder house ventilation and sanitation may induce certain irritations of the eyes and nostrils, which become prime targets for picking. Keep litter dry to prevent the buildup of feces on the toes of young birds ("toe balls"); such buildup can result in the loss of toes.

- Equipment. Poorly designed pens, feeders, or water fountains with sharp edges can cause injuries that attract the attention of other birds and prompt them to begin picking.

- External parasites. Lice or mite infestations can cause itching and irritation, and cause a bird to pick its feathers.

- Territorial aggression. Most male game birds become very aggressive during courtship and mating. Overcrowded conditions, whether in a range area or a small mating pen, intensify picking. 
- Nutrition. The incidence of cannibalism is usually higher in flocks that are fed rations high in energy and low in fiber. You can add fiber in the form of oats to help reduce picking.

Cannibalism can occur under the most favorable management conditions, so it is essential that you observe the birds' behavior daily, watching for any problem. The following management practices will help minimize problems with cannibalism:

- Provide the game birds with adequate shelter and ground cover.

- Have adequate floor pen space for the birds.

- Provide adequate eating and drinking space.

- Eliminate obstacles in floor or pen that may cause injury.

- Remove dead, sick, or weak birds from the flock immediately.

- Do not introduce a few new birds into an established population.

- Provide escape cover and diversions in pens (fig. 19).

- Avoid frightening the birds and isolate the flight pens from human, animal, and vehicle traffic.

- Do not make sudden changes in the texture of feed.

- Avoid sudden changes in temperature when moving young birds from brooder house to a range area.

- Use proper mechanical devices or methods for control of cannibalism.

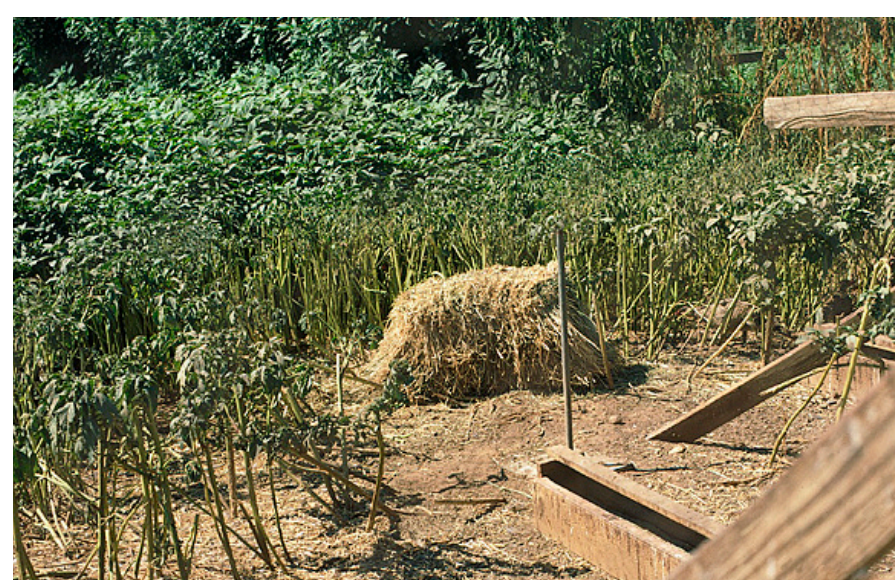

Figure 19. Bale of hay used in flight pen to provide birds with something to do, and thus deter picking and cannibalism of pen mates.
- Lighting: Use dim light in brooders.

- Specs: Reduce picking and egg eating by fitting the birds with specs (plastic blinders) (fig. 20).

- Hoods: Hoods are available in several designs and can be used during the growing, holding, and breeding periods (fig. 20).

- Bits: Reduce picking by using a bit to prevent the bird from closing its beak. Bits are most often used for quail.

- Beak trimming: Proper removal of no more than one-third of the upper bill can greatly reduce injury due to picking (fig. 21). Commercial hot-blade trimmers used for chickens work equally well for game birds. Heavy nail clippers can also be used to trim the bill.
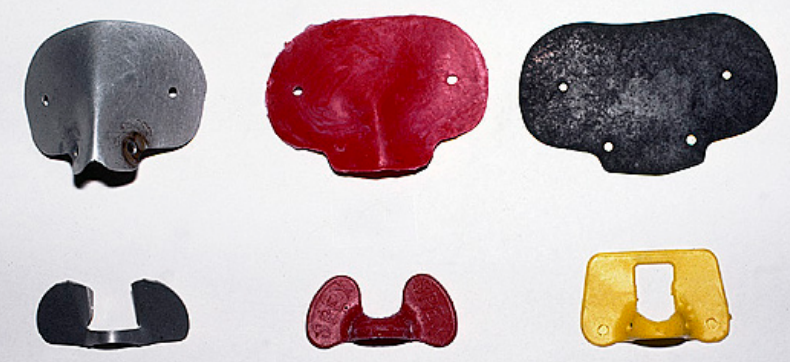

Types of hoods and plastic blinders (specs)

Figure 20. Anti-picking devices used on game birds.

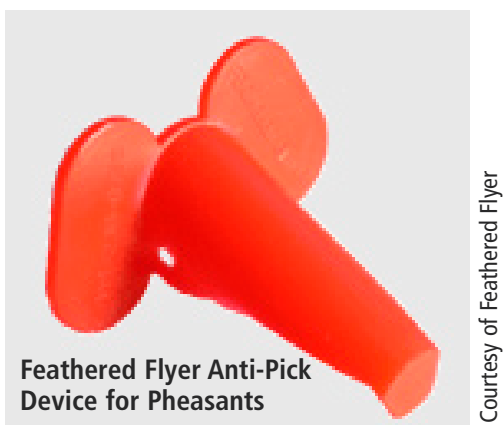




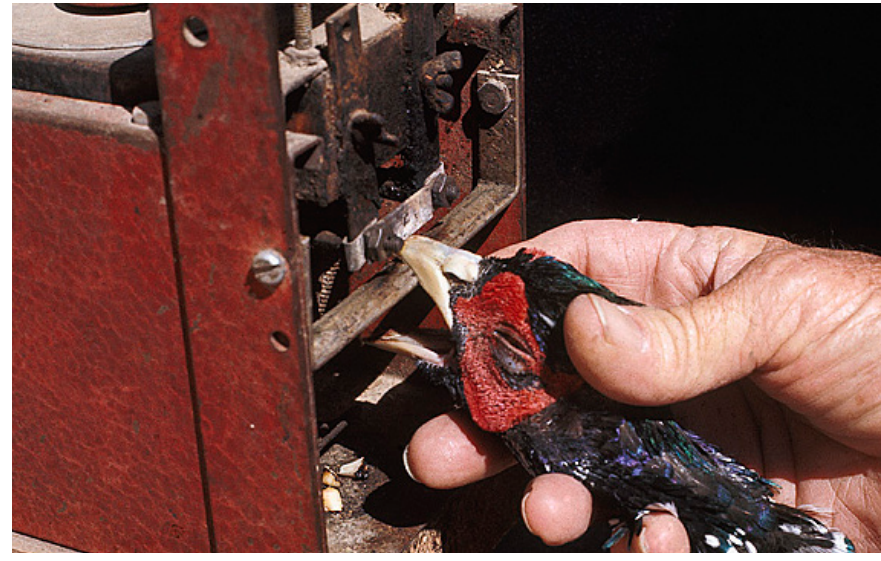

Figure 21. Beak trimming with an electric trimmer.

\section{RODENT CONTROL}

Norway rats, roof rats, and house mice are universal pests. They are controlled more successfully by exclusion than by attempts at removal, but given enough time they still seem to be able to invade even the best and tightest of brooder houses and feed storage rooms.

Rat and mouse control using poison baits can be difficult in a game bird operation because there is such an abundance of alternative, attractive feed. Traps offer a better solution in this case, but trapping can be slow, never-ending work. Because their living and eating habits are so different, rats and mice are controlled by different techniques. A common error is to consider rats and mice as one problem and to try to solve it with one control effort. This approach usually fails.

There are many poisons that, if properly used, can control rat and mouse populations. Contact your local agricultural commissioner or Cooperative Extension office to find out which poisons and poisoning techniques they recommend.

The successful trapping of rats or mice is more an art of "where" than of "how." There are many good baits; almost any food that you can place on the trap's trigger will be effective. Runway setting without bait is sometimes more effective. For both rat and mouse traps, an enlarged bait pan made from cardboard or light screen wire greatly improves results. It is important to set traps across the paths used by rats and mice-next to walls and between obstacles. You can use boxes or sacks to form obstacles that will force the rodents to pass over the trap's trigger. Two or more traps set close together work well where there are many rats and mice or where there are trap-shy individuals. If you do set traps, use plenty of them. If the rodents travel overhead, you can fasten rat or mouse traps to pipes, walls, or rafters. It is not necessary to clean or boil the traps or handle them with gloves; rats and mice are accustomed to human odors.

\section{PREDATOR CONTROL}

When you are dealing with predators, exclusion is perhaps an even more important approach than when you are dealing with rodents, because even one visit from a fox, mink, raccoon, bobcat, or skunk can be very costly in terms of birds killed. Enclosed flight pens, if properly constructed, should do the job, but the mesh ordinarily will not exclude weasels or snakes, and certainly not rats and mice.

Damage to birds can result from fright if a predator outside the wire panics them, even if the predator does not enter the pen for direct killing. Because of this, you may want to effect some reduction of predators in the surrounding area.

Skunks seem to be everywhere and are an important nuisance. When it attacks a bird flock, a skunk usually kills only one victim. Skunk predation can usually be identified by the predator's clumsy mauling of the bird.

Opossums also maul their victims and also do a messy job of smashing eggs in the pen if they gain entrance.

Weasels are very neat killers, usually biting the bird through the skull, the back of the neck, or under the wing. They don't stop with one, though; they may kill many birds in one night and place them in a neat pile.

Rats, too, are ruthless killers and, like the weasel, they often pile their victims in a corner. They usually kill by slitting the bird's throat and are very slick at not dis- 
turbing the entire flock. A rat will usually eat more from the carcass than a weasel will, often pulling the bird partly into its burrow. Young birds and eggs will disappear completely.

Foxes do not usually kill a great number of birds at one time, and they carry off their victims.

Raccoons eat the heads off as many birds as possible, and they are persistent. Raccoons are clever and very strong, excellent hunters.

Feral (wild) dogs and cats are a menace to any ground-dwelling wild birds. The cats are more likely to be a problem if there is sufficient heavy cover for them to hide in.

If you find it necessary to control any of these predators, the most selective method is to shoot them. Trapping with steel traps is effective if you can do it without endangering bird dogs or other nontarget animals and if the operator has the right traps and knows how to use them. In many cases, a live trap is easier for an inexperienced trapper to use, and it is safer. Nontarget animals that are caught accidentally can be released unharmed.

\section{PROCESSING GAME BIRDS}

You can modify the procedures conventionally used to process fowl and apply them to most game birds. The size of the processing equipment and the degree of mechanization will depend on the number of birds you will want to process. A procedure for processing game birds is laid out below.

\section{Regulations}

Laws regulating the processing and sale of bird meats differ among states. Make sure to check with your state Department of Agriculture and local agencies for requirements on the processing and sale of game bird meats.

\section{Slaughter Method}

Hang the bird by its feet on the killing rack, sever its jugular vein behind the lower jaw, and allow the blood to drain. This technique removes one-third to one-half of the blood from the carcass.

\section{Picking}

To remove the feathers, immerse the carcass for 60 to 90 seconds in water heated to subscalding-about $140^{\circ} \mathrm{F}\left(60^{\circ} \mathrm{C}\right)$. Test the ease of feather removal by pulling a few tail or wing feathers. Remove feathers by hand or by machine immediately after scalding. A tub-type picking machine equipped with rubber fingers on the sides and bottom of the drum is preferred over the reel-type picker that requires the operator to hold each bird when removing its feathers. After you remove the feathers, wash the carcass thoroughly to eliminate soiled areas and reduce the number of microorganisms on the skin surface.

\section{Evisceration}

Remove the feet at the hock joint. Remove the oil gland on the tail: start 1 inch (2.5 $\mathrm{cm}$ ) forward of the gland, then cut to the end of the tail. Cut the head off. Split the neck skin, starting from the shoulders and going to the end of the neck, and pull the skin from the neck. Remove the trachea (windpipe) and esophagus (gullet) with the crop, and cut off the neck. Cut around the vent and gently pull until a few inches of the intestines are out. About halfway between the tip of the breast and vent make a crosswise cut about 3 inches $(7.6 \mathrm{~cm})$ long. Pull the vent and intestines through the cut and remove the viscera. Remove the giblets—-the heart, liver, and gizzard-and 
place them in a clean container for further processing. Remove all other organs, with particular attention to the lungs, making certain that the body cavity is clean.

\section{Packaging}

Thoroughly wash the carcass and giblets. Chill for several hours in ice water kept at $40^{\circ} \mathrm{F}\left(4^{\circ} \mathrm{C}\right)$. Remove from the water, and drain. Place giblets in a small plastic bag or wrap them in waxed paper and place them inside the carcass. Tuck the legs of the carcass under the strip of skin left by the crosswise cut below the breast. Place the carcass in a plastic bag, draw out as much air as possible, and tie the bag. You can force air out of the plastic bag with a vacuum pump or by submerging the bag in water far enough to cover the carcass but not so far as to allow water to enter the bag.

Place the dressed birds in suitable shipping containers and cover them with crushed ice or dry-pack them with $\mathrm{CO}_{2}$ snow (dry ice) for shipment to market. (Caution: Do not handle dry ice with your bare hands. It will freeze your skin quickly.)

\section{Meat Quality}

"Quality" in game bird meat may mean different things to different people. The present-day consumer judges quality on the basis of tenderness, moisture, and flavor.

Two factors affecting the quality of game bird meat are the scalding and aging temperatures. Scald your birds according the instructions given above and at the temperature indicated. Then place the freshly cleaned carcass in slush ice for several hours (for chilling) and refrigerate it. Proper aging time for adequate tenderization of the meat is about 18 to 24 hours. After that, the meat can be cooked or frozen.

\section{Spoilage}

The processor must follow proper handling and storage procedures to produce a wholesome product. Spoilage of game bird meat results mostly from the development of microorganisms. Only a few species of psychrophilic (cold-loving) organisms cause spoilage in the meat. Freshly killed poultry contains approximately 1,000 to 10,000 microorganisms per square centimeter ( 1 square $\mathrm{cm}=0.16$ square in) of surface area. Poultry will usually spoil when the number of bacteria reaches 1 to 10 million per square centimeter. The first indication of spoilage is off-odor. Certain organisms also cause a change in flavor when their numbers exceed the safe level. To help sanitize processing plants, some processors use chlorinated water to clean equipment and chill the birds.

\section{GAME BIRD ORGANIZATIONS}

Many game bird producers and hunting club operators join the North American Gamebird Association (NAGA). For information, contact NAGA, 1214 Brooks Ave., Raleigh, NC 27607 or visit the NAGA web site: http://www.naga.org.

\section{GLOSSARY FOR GAME BIRD GROWERS}

bit. A metal ring attached to a bird's upper beak so that the beak doesn't close tightly; helps prevent picking and cannibalism.

blastoderm without embryo (BWE). When candled, a BWE egg shows a blood ring; on breakout there are no visible embryo structures.

blastodisc. The small, disc-shaped region on the yolk that contains the egg nucleus.

blood ring. A circular blood remnant visible when an egg is candled; signifies that the embryo has died at a young age. 
breakout. The opening of an egg to examine its contents and determine whether the blastodisc has been fertilized or whether embryonic structures are present.

candled fertility. The percentage of eggs that remain after clears are removed by candling; compare with true fertility.

candled out. Of clears, removed from the incubator after candling.

candling. Examination of a backlit, intact egg to determine the presence or absence of a viable embryo. Also used to look for shell defects before setting.

clear. An incubated egg that appears clear when candled, indicating that it does not contain a live embryo.

cystic embryo. An embryo that dies early in gestation; on breakout, its appearance is similar to that of BWE except that embryo tissue is visible.

dry-bulb temperature. Temperature measured with a standard thermometer or electronic sensor; used in combination with wet-bulb temperature and a psychrometric chart to determine relative humidity.

embryo. An organism in the early stages of its development; a bird is an embryo before hatching.

fertile, no development (FND). A rarely diagnosed condition in which the blastodisc was fertilized but died before the egg was laid or before growth could be initiated in the incubator.

fertile, preovipositional death. A rarely diagnosed condition characterized by a blastodisc that appears to be fertile but dies before the egg is laid by the hen.

germ or germinal disc. Fertilized blastodisc; the embryo has about 50,000 cells when the egg is laid.

hatch, percent hatch, hatching percent, or hatch of total. Percentage of all eggs set that hatch, regardless of whether the eggs were fertile (a typical hatch might be 70 to 90 percent).

hatch of fertile eggs or hatchability. Percentage of fertile eggs that hatch (should be above 85 percent).

hatcher. Machine used to maintain proper conditions for embryos during the final few days (usually three days) before hatching.

hood. A device used to obstruct a bird's forward vision and prevent cannibalism.

inbred. Of a bird or flock, having some degree of inbreeding.

inbreeding. The result of mating closely related birds, such as father to daughter or brother to sister. As the rate of inbreeding increases, the stock's ability to reproduce usually declines.

incubation. Maintenance of the temperature and humidity needed to initiate embryo growth and hatching for avian eggs, whether by a female bird or by an artificial machine.

incubator or setter. A machine that maintains proper conditions for incubation or setting of avian eggs.

malposition. In a hatching chick, any position except the head under the right wing and positioned in the large end of the shell; for example, the head under the left wing and the head between the legs both are malpositions.

pip. An egg in which the chick has broken the shell in an attempt to hatch; also, the act of breaking the shell. Chicks may die after pipping or may be unable to get out of the shell, but most chicks do hatch successfully.

positive development (PD). Eggs that are candled out as clears because there is no blood formation; the germ was fertile, but it died soon after cell growth resumed when the egg was warmed above $80^{\circ} \mathrm{F}\left(26.7^{\circ} \mathrm{C}\right)$.

relative humidity. A measure of the water vapor or moisture in air; it can be determined by comparing the wet-bulb and dry-bulb temperatures using a psychrometric chart. Electronic sensors are now available to measure the relative 
humidity of air in incubators and egg storage rooms without the use of wetbulb and dry-bulb thermometers.

set. To place eggs in an incubator or under a female for incubation.

specs. Plastic blinders attached to a bird's bill to prevent pecking and cannibalism. true fertility. The percentage of eggs that are fertile in an incubator or hatcher. This can be determined only through incubation, candling, and breakout of the clears to determine which eggs were fertile or by breaking out potentially fertile eggs to examine their germinal disc. For example, you might examine a sample in order to estimate the fertility of a flock.

wet-bulb temperature. The temperature measured by a standard thermometer equipped with a wet sock over the bulb; used in combination with dry-bulb temperature and a psychrometric chart to determine relative humidity. For accurate measurement, air must be moving over the wet sock to provide evaporation.

\section{REFERENCES}

Ernst, R. A. 2004. Hatching egg sanitation: The key step in successful storage and production. Oakland: University of California Division of Agriculture and Natural Resources Publication 8120. http://anrcatalog.ucdavis.edu.

Ernst, R. A., F. A. Bradley, M. E. Delany, U. K. Abbott, and R. M. Craig. 2004. Common incubation problems: Causes and remedies. Oakland: University of California Division of Agriculture and Natural Resources, Publication 8127. http://anrcatalog.ucdavis.edu.

Mullin, J., 1991. Game bird propagation: The wildlife harvest system. Goose Lake, Iowa: Wildlife Harvest Publications.

Siopes, T. D., and W. O. Wilson. 1973. Determination of the sex of chukar partridges at hatching. Journal of Wildlife Management 37(2):239-240.

Woodard, A., P. Vohra, and V. Denton. 1993. Commercial and ornamental game bird breeders handbook. Surrey, B.C., Canada: Hancock House Publishers, Ltd.

\section{FOR MORE INFORMATION}

You'll find related information in these titles and in other publications, slide sets, CD-ROMs, and videos from UC ANR:

Common Incubation Problems: Causes and Remedies, Publication 8127

Egg Candling and Breakout Analysis, Publication 8134

Hatching Egg Breakout, Video V86-W

Hatching Egg Sanitation: The Key Step in Successful Storage and Production, Publication 8120

To order these products, visit our online catalog at http://anrcatalog.ucdavis.edu. You can also place orders by mail, phone, or FAX, or request a printed catalog of publications, slide sets, CD-ROMs, and videos from

University of California

Agriculture and Natural Resources

Communication Services

6701 San Pablo Avenue, 2nd Floor

Oakland, California 94608-1239

Telephone: (800) 994-8849 or (510) 642-2431

FAX: (510) 643-5470 


\section{E-mail inquiries: danrcs@ucdavis.edu}

An electronic version of this publication is available on the ANR Communication Services website at http://anrcatalog.ucdavis.edu.

\section{Publication 8155}

ISBN-13: 978-1-879906-98-3

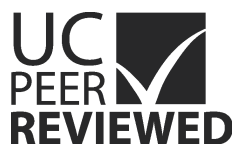

This publication has been anonymously peer reviewed for technical accuracy by University of California scientists and other qualified professionals. This review process was managed by the ANR Associate Editor for Animal, Avian, Aquaculture, and Veterinary Sciences.

(C)2007 by the Regents of the University of California

Division of Agriculture and Natural Resources.

All rights reserved.

To simplify information, trade names of products have been used. No endorsement of named products is intended, nor is criticism implied of similar products that are not mentioned.

The University of California prohibits discrimination or harassment of any person on the basis of race, color, national origin, religion, sex, gender identity, pregnancy (including childbirth, and medical conditions related to pregnancy or childbirth), physical or mental disability, medical condition (cancer-related or genetic characteristics), ancestry, marital status, age, sexual orientation, citizenship, or status as a covered veteran (covered veterans are special disabled veterans, recently separated veterans, Vietnam era veterans, or any other veterans who served on active duty during a war or in a campaign or expedition for which a campaign badge has been authorized) in any of its programs or activities.

University policy is intended to be consistent with the provisions of applicable State and Federal laws.

Inquiries regarding the University's nondiscrimination policies may be directed to the Affirmative Action/Staff Personnel Services Director, University of California, Agriculture and Natural Resources, 300 Lakeside Drive, $6^{\text {th }}$ Floor, Oakland, CA 94612-3550, (510) 987-0096. For information about obtaining this publication, call (800) 994-8849. For downloading information, call (530) 297-4445.

pr-2/07-WJC/CAM 